\title{
Shadow Banking in Europe: \\ Idiosyncrasies and their Implications for Regulation
}

\author{
Hossein Nabilou* \\ André Prüm**
}

\begin{abstract}
This paper studies the specificities of the regulation of shadow banking in Europe. It argues that the idiosyncratic features of the EU shadow banking sector call for a different (or indigenized) regulatory approach from that of the US. It highlights striking differences between the EU and the US shadow banking sectors based on both market structure and legal micro-infrastructure of the shadow banking sectors in these two jurisdictions. These different institutional and legal infrastructures of the shadow banking activities, instruments, and entities, as well as the different trajectories in the evolution of the banking and shadow banking sectors in terms of business models, size and composition of actors and transactions can be the driving force behind the differential regulatory treatment of shadow banking in the EU and the US.

In highlighting the differences between shadow banking across the Atlantic, this paper focuses on the repo markets, as the main instruments and activities that play a significant role in credit intermediation outside the regulatory perimeter of the traditional or regular banking system. It then discusses one specific segment of the shadow banking entities, i.e., Money Market Funds (MMFs), and highlights the fundamental differences in the structure, functioning, and existing regulatory treatment of the MMFs in the US and the EU. The paper concludes that the market structure, business models, as well as legacy legal and regulatory frameworks of shadow banking (as well as banking) display substantial differences in the US and the EU. The findings in this paper rally against one-size-fits-all approaches to addressing the problems of the shadow banking system worldwide and recommends differentiated and more nuanced regulatory approaches to regulating shadow banking across the Atlantic. By implication, any adoption of the US regulatory framework or recommendations of international fora for the shadow banking sector by the EU regulatory authorities should not overlook these differences.
\end{abstract}

Keywords: Shadow banking, securities financing transactions, money market funds, securitization, rehypothecation.

JEL Classification: F3, G1, G2, G3, K2, N2

\footnotetext{
* Postdoc in Banking and Financial Law; University of Luxembourg; Faculty of Law, Economics and Finance; hossein.nabilou@uni.lu

** Professor of law, Chair in Banking, Financial and Business Law; University of Luxembourg; Faculty of Law, Economics and Finance; andre.prum@uni.lu

The authors are grateful to Michael Grill of the ECB for his insights and helpful comments, and participants of the European Banking Institute Global Annual Conference on Banking Regulation (23 \& 24 February 2018) held in Frankfurt.
} 


\section{Introduction}

Despite the significant role of shadow banking in the Global Financial Crisis (GFC), ${ }^{1}$ and heavy involvement by regulators to curb its risks, the concept of shadow banking remains imprecise and elusive. The lack of a precise definition is a potential source of a whole host of problems, including imprecise measurement of shadow banking in different jurisdictions. ${ }^{2}$ For practical purposes, in this paper we define shadow banking by its function, i.e., the role it plays in the economy and the risks it poses to the financial system. In this view, shadow banking can best be understood as undertaking financial intermediation (credit, maturity and liquidity transformation) outside the banking regulatory perimeter and without access to government safety nets (e.g., deposit insurance, lender of last resort). Shadow banking activities can be undertaken either by banking institutions engaging in shadow banking activities or by any other institution (non-banks) engaging in financial intermediation often using financial instruments lying outside the scope of government safety nets (e.g., repos and certain derivatives). ${ }^{3}$

In this view, shadow banking is a whole that is greater than the sum of its parts. It is a combination of activities, instruments and entities that would collectively pose greater risks than they would each in isolation. But the paradox is that the whole, as an elusive and slippery concept, does not lend itself to the governance of legal rules, and it is only the constituent parts of the whole that can be captured by legal provisions. This is why we rarely see any reference to shadow banking in laws and regulations. Instead, the references to each segment of the shadow banking sector abound in legal and statutory texts. By the same token, instead of focusing on the macro-level analysis of the shadow banking sector, this article studies the micro-level distinctions in the structure and legal treatment of the shadow banking in the US and the EU.

The overarching rationale for regulating shadow banking is the concerns about systemic risk. ${ }^{4}$ Systemic risk in the shadow banking sector can materialize either directly or indirectly. Directly, systemic risk originates from credit intermediation (maturity and liquidity transformation), leverage and imperfect credit risk transfer, ${ }^{5}$ and indirectly through the interconnectedness of the shadow banking system with the

\footnotetext{
${ }^{1}$ Gary B. Gorton, Slapped by the Invisible Hand: The Panic of 2007 (New York: Oxford University Press, 2010).

${ }^{2}$ See for example, Christophe Duclos and Romuald Morhs, "Analysis on the Shadow Banking Content of Captive Financial Companies in Luxembourg," (Luxembourg: Banque Centrale du Luxembourg, Comité du Risque Systémique, 2017). The definition in the shadow banking is of special significance because if not properly defined, it can create a whole host of problems in the collection of data on shadow banking. For example, there are huge discrepancies in the available data on shadow banking the majority of which have their roots in the different approaches taken to define shadow banking.

${ }^{3}$ For different approaches to the definition of shadow banking see Hossein Nabilou and Alessio Pacces, "The Law and Economics of Shadow Banking," in Research Handbook on Shadow Banking: Legal and Regulatory Aspects, ed. Iris H. Chiu and Iain G. MacNeil (Cheltenham, UK: Edward Elgar Publishing Inc., 2018).; International Monetary Fund, "Global Financial Stability Report: Risk Taking, Liquidity, and Shadow Banking: Curbing Excess While Promoting Growth," (Washington, DC: International Monetary Fund, October 2014).

${ }^{4}$ Eddy Wymeersch, "Shadow Banking and Systemic Risk," European Banking Institute Working Paper Series No. 1 (2017).

${ }^{5}$ Viral V. Acharya, Philipp Schnabl, and Gustavo Suarez, "Securitization without Risk Transfer," Journal of Financial Economics 107 , no. 3 (2013).
} 
traditional banking system. ${ }^{6}$ Following the systemic risk logic for regulating the shadow banking system, this study focuses on the parts of the shadow banking sector that are likely to create or contribute to systemic risk.

In exploring the specificities of the shadow banking in the EU compared to its US counterpart, we first focus on the securities financing markets and underline the distinguishing features of the European repo markets from its US counterpart. Second, we focus on shadow banking entities and in particular on money market funds (MMFs) and analyze the structure of such funds and highlight their differences and the implications of such distinctive features to MMF regulatory regime in Europe. Due to limitations of time and space, securitization, derivatives markets and other non-banks engaging in shadow banking activities will remain outside the scope of this paper.

\section{International initiatives to regulate shadow banking}

The shadow banking system, as part of the broader financial ecosystem, has evolved differently in different jurisdictions. For example, in developing countries shadow banking has emerged significantly differently from the shadow banking system in developed countries. ${ }^{7}$ The main contention of this paper is that idiosyncrasies in the development of the shadow banking system exist in various jurisdictions in the western hemisphere as well. This has been the case despite the international efforts to harmonize the shadow banking instruments such as repos. Therefore, this paper aims at underlining such differences that require a differential regulatory treatment in the two main shadow banking jurisdictions, i.e., the EU and the US. ${ }^{8}$

The focus of international efforts and transatlantic regulatory reforms have been on addressing the fragility of the shadow banking system by regulating the liquidity and leverage and incentivizing financial institutions to reduce their leverage, improve their liquidity conditions, and specifically reduce their reliance on short-term wholesale funding. At the international level, the main regulatory initiatives on the reforms of the shadow banking sector are carried out by the Financial Stability Board (FSB). In 2011, the FSB put

\footnotetext{
${ }^{6}$ See, for example, Financial Stability Board, "Shadow Banking: Scoping the Issues, a Background Note of the Financial Stability Board," (2011), 4.

7 Viral V. Acharya, Hemal Khandwala, and T. Sabri Öncü, "The Growth of a Shadow Banking System in Emerging Markets: Evidence from India," Journal of International Money and Finance 39 (2013).

See also Swati Ghosh, Ines Gonzalez del Mazo, and İnci Ötker-Robe, "Chasing the Shadows: How Significant Is Shadow Banking in Emerging Markets?," The World Bank- Economic Premise, no. 88 (2012).

${ }^{8}$ The differential transatlantic trajectories taken by the shadow banking sector is not only due to the differences in the legal systems and financial regulation, but also due to economic reasons (e.g., supply and demand for shadow-banking products and services due to local specificities, and different needs of consumers). However, this paper is to highlight the difference in the shadow banking in the EU and the US based on the legal infrastructure and regulatory treatment of the institutions and instruments that are generally perceived to belong to shadow banking entities or instruments.
} 
forward five overarching principles and work streams to identify and regulate the key risks in the shadow banking system. ${ }^{9}$ These work streams include:

1. Indirect regulation or regulating banks' interactions with shadow banking entities to limit spillovers between regulated banks and shadow banks;

2. Regulatory reform of MMFs to reduce the risk of runs on MMFs; $;^{10}$

3. Regulation of other shadow banking entities to identify the potential systemic risks of the new shadow banking entities;

4. Regulation of securitization to align incentives in the securitization transactions;

5. Regulation of securities lending and repos - and addressing the risks and procyclicality of such activities and instruments. ${ }^{11}$

The FSB and other international fora have been criticized for imposing their policy priorities to all jurisdictions without due regard to the idiosyncrasies of different markets all around the globe. In particular, Chinese legal scholars have been critical of the international initiatives for the regulation of the shadow banking sector and have claimed that the FSB and the Basel Committee on Banking Supervision (BCBS), as global standard setters, have ignored the nuances of local markets. ${ }^{12}$ In this paper, we highlight significant differences, both regarding market structure and regulatory regime, in the seemingly similar EU and US shadow banking sector to put a spotlight on such differences and attract international standard setters' attention to such idiosyncrasies. A close examination of the existing recommendations, preparatory works

\footnotetext{
${ }^{9}$ See Financial Stability Board, "Shadow Banking: Strengthening Oversight and Regulation-- Recommedations of the Financial Stability Board," (2011). See also "Strengthening Oversight and Regulation of Shadow Banking: Policy Framework for Strengthening Oversight and Regulation of Shadow Banking Entities," (Financial Stability Board, 2013).

${ }^{10}$ The FSB's work on addressing the risks of the asset management industry is particularly focused on addressing the mismatch between the liquidity of a fund's investments and redemption terms for funds. It is further concerned with the leverage within the investment fund industry, operational risks associated with transferring investment mandates in stressed conditions, and securities lending activities of asset managers and funds. See European Central Bank, Financial Stability Review (May 2016), 106-08.

${ }^{11}$ See Board, "Shadow Banking: Strengthening Oversight and Regulation-- Recommedations of the Financial Stability Board." See also "Strengthening Oversight and Regulation of Shadow Banking: Policy Framework for Strengthening Oversight and Regulation of Shadow Banking Entities."

12 Robin Hui Huang, "Shadow Banking and Its Regulation: The Case of China," in Reconceptualising Global Finance and Its Regulation, ed. Ross P. Buckley, Emilios Avgouleas, and Douglas W. Arner (New York: Cambridge University Press, 2016 ), 348. It appears that China is not unique in its shadow banking being different from the rest of the Western economies. In neighboring India, it is also found that unlike western economies where the growth of the shadow banking sector is driven by a desire to mitigate counterparty risks by providing 'safe' collateral for financial transactions, or for the purposes of regulatory arbitrage, the shadow banking sector is a substitute for direct lending by banks in non-urban India. See Acharya, Khandwala, and Sabri Öncü, "The Growth of a Shadow Banking System in Emerging Markets: Evidence from India."; Acharya, Schnabl, and Suarez, "Securitization without Risk Transfer." (They find that securitization vehicles are mainly motivated by and used for regulatory arbitrage.)

See also Yingmao Tang, "Shadow Banking or "Bank's Shadow": Reconceptualising Global Shadow Banking Regulation," in Reconceptualising Global Finance and Its Regulation, ed. Ross P. Buckley, Emilios Avgouleas, and Douglas W. Arner (New York: Cambridge University Press, 2016), 329, 37-38.; William Blair, "Reconceptualizing the Role of Standards in Supporting Financial Regulation," ibid., 445-46.
} 
and decision-making mechanisms within such international fora suggests that international financial fora are largely cognizant of such differences and in many instances take such specificities into account, however, familiarity with these idiosyncrasies would benefit not only international standard setters, but also national regulators responsible for implementing such guidelines and recommendations in their specific jurisdictions. Therefore, there is still a need for a nuanced tone for international fora as their recommendations set standards towards which almost all national regulators anchor, particularly those regulators with limited regulatory resources.

For example, in 2012, the International Organization of Securities Commissions (IOSCO) recommended the conversion of Constant Net Asset Value Money Market Funds (CNAV MMFs) to Variable Net Asset Value Money Market Funds (VNAV MMFs). ${ }^{13}$ It further recommended that if such a conversion proves to be impossible, safeguards should be in place to reinforce CNAV MMFs' resilience in the event of significant redemptions. The FSB also joined forces with the IOSCO in supporting the idea that in the event of the impossibility of the conversion of CNAV to VNAV funds, requirements that are functionally equivalent to capital, liquidity, and other prudential requirements that protect banks against runs on their deposits should be in place for CNAV MMFs. ${ }^{14}$ These two international fora also supported imposing reserve requirements on MMFs and risk-retention requirements for the suppliers of securitization (e.g., originator, sponsors). ${ }^{15}$ As we shall see in the next sections many of the such proposals were wanting in their theoretical substance as well as empirical evidence.

The proposal for conversion of CNAV funds to VNAV funds has received a lukewarm support from the very first day and eventually neither jurisdictions adopted it. The proposal for imposing reserve requirements (so called 'NAV buffer') faced strong resistance from the industry and was eventually dropped. However, the policy diverged in the case of sponsor support. In the EU, the European regulators preferred to put a ban on sponsor support, while the US regulator opted for a more nuanced approach; allowing such support but imposing transparency requirements. The proposals put forward on securitization, which is mainly about retention requirements, despite being adopted in the EU and the US, perhaps was not necessary as many originators have already retained more than the required risks in the securitization positions. ${ }^{16}$

\footnotetext{
${ }^{13}$ International Organization of Securities Commission (IOSCO), "Policy Recommendations for Money Market Funds," (October 2012).

${ }^{14}$ Financial Stability Board, "Strengthening Oversight and Regulation of Shadow Banking: An Integrated Overview of Policy Recommendations," (Basel: Financial Stability Board, 18 November 2012).

15 "Shadow Banking: Strengthening Oversight and Regulation: Recommedations of the Financial Stability Board," (2011).

${ }^{16}$ See for example, Paul Willen, "Mandated Risk Retention in Mortgage Securitization: An Economist's View," American Economic Review 104, no. 5 (2014).
} 
In addition to the efforts of the international fora, self-regulatory organizations as well as industry associations have played a significant role in the legal treatment of the shadow banking instruments and activities. These players have a rather different approach compared to international fora. Unlike the international fora, which focus on the mitigating risk to the financial system in the aggregate and at macrolevel, these associations focus on the harmonization of shadow banking instruments at the micro-level (e.g., contract design, bankruptcy protections, etc.) inspired by the commercial and financial customs and practices already in place. For example, efforts to standardize and harmonize the transactions largely used in the shadow banking sector have been underway well before the GFC. Industry initiatives through selfregulatory organizations, such as International Capital Market Association (ICMA), Securities Industry and Financial Markets Association (SIFMA), and International Swaps and Derivatives Association (ISDA) have been relatively successful in achieving certain degrees of standardization in the design, governance, and regulation of such transactions. The ICMA (and its predecessor institutions) played a significant role in pushing governments to pass laws that grant bankruptcy safe harbors to repos and certain types of derivatives with certain counterparties. However, despite such efforts toward standardization, many transactions used in the shadow banking system remain subject to local rules and regulations of specific jurisdictions. This is the case especially in Europe where those transactions are still governed and regulated by the Member State laws, subject to varying degrees of harmonization. In the next section, we present the root causes of such subtle idiosyncrasies that drive the divergence in the shadow banking systems of Europe and the US.

\section{Specificities of the shadow banking in the EU: a long divergence}

At the roots of the differences in the EU and US shadow banking system lies deeper structural differences in the financial market within these two jurisdictions. ${ }^{17}$ There are at least two significant contributing factors to the divergent paths of the evolution of shadow banking on either side of the Atlantic. The first is related to the fact that, roughly speaking, Europe has a bank-based financial system ${ }^{18}$ and the US has a market-

\footnotetext{
${ }^{17}$ A word of caution is in order at this very outset. In comparing the shadow banking in the EU and the U.S., one should bear in mind that the EU is not composed of homogenous financial markets and intuitions. Instead, there is a large variety of heterogeneous institutions in various jurisdictions; some with close similarities to the U.S. markets, some a far cry from it. For example, the European Banking Authority (EBA) (2014) and ESRB 2016 report suggests, there is a wide variety of treatment of non-bank financial institutions across EU Member States. See: European Banking Authority, "Report to the European Commission on the Perimeter of Credit Institutions Established in the Member States," (London27 November 2014).

This adds to the complexity of comparing the shadow banking sector in these two jurisdictions and provides a compelling argument for a differential regulatory treatment of shadow banking in the EU compared to the US.

${ }^{18}$ Ross Levine, "Bank-Based or Market-Based Financial Systems: Which Is Better?," Journal of Financial Intermediation 11, no. 4 (2002). See also European Commission, "Economic Analysis Accompanying the Document Communication from the Commission to the European Parliament, the Council, the European Economic and Social Committee and the Committee of the Regions Action Plan on Building a Capital Markets Union," Commission Staff Working Document (Brussels: European Commission, 2015), 18-25.
} 
based one. ${ }^{19}$ The second concerns the banking business model across the Atlantic. Namely, European financial markets are dominated by universal banks, while the modern US banking has been characterized with the separation of the investment banking from the commercial banking model, largely emerged after the great depression by the enactment of the Glass-Steagall Act. ${ }^{20}$

To highlight the role of bank-based vs. market based financial system, the data on the liabilities side of the EU and US corporate sector's balance sheet is very much revealing. In the bank-based financial markets of Europe, data from 2013 suggest that $14 \%$ of the total liabilities of European companies is made up of bank loans. To the contrary, in the US, the share of bank loans in total liabilities of companies stands at $3 \%$. Equally importantly, $11 \%$ of the total liabilities of US companies are in the form of corporate bonds, compared to $4 \%$ in the European companies. ${ }^{21}$

\section{Chart 6: Liabilities of the EU corporate sector, EU-28 non-financial corporations, 2013}

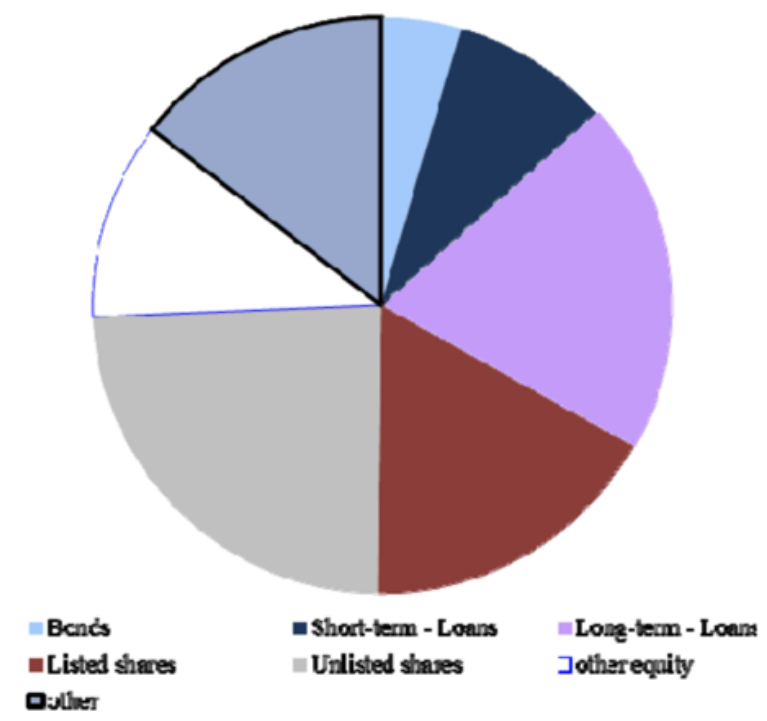

Source: Eurostat.

\section{Chart 7: Liabilities of the US corporate sector, non- financial corporations, 2013}

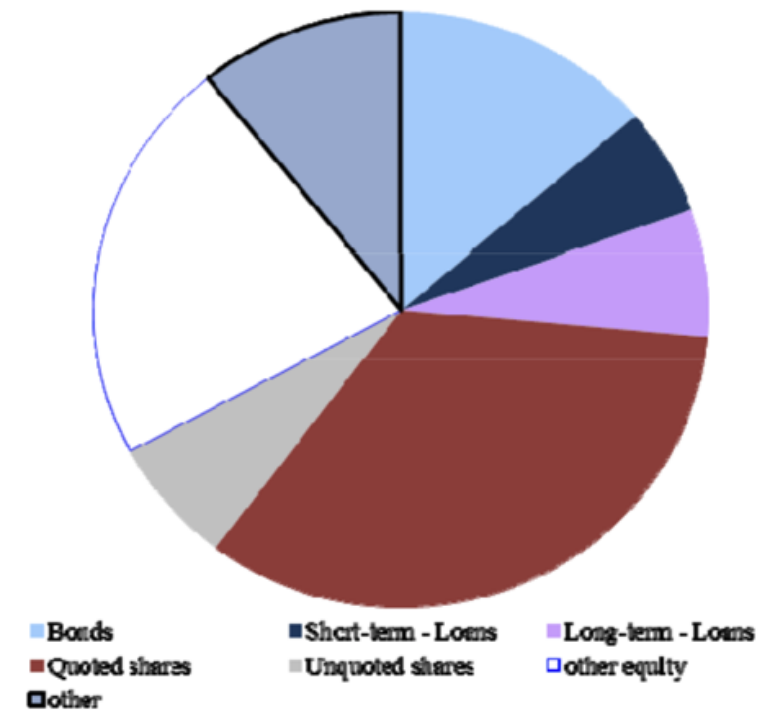

Source: OECD.

\footnotetext{
${ }^{19}$ Levine, "Bank-Based or Market-Based Financial Systems: Which Is Better?."

${ }^{20}$ Anthony Saunders and Ingo Walter, Universal Banking in the United States: What Could We Gain? What Could We Lose? (New York: Oxford University Press, 1994).; Hossein Nabilou, "Can the Plight of the European Banking Structural Reforms Be a Blessing in Disguise?," SSRN Working Paper Series (2019).

${ }^{21}$ Commission, "Economic Analysis Accompanying the Document Communication from the Commission to the European Parliament, the Council, the European Economic and Social Committee and the Committee of the Regions Action Plan on Building a Capital Markets Union," 18-25. The difference between bank-based and market-based financial systems even shapes the mechanisms of central bank interventions in financial markets in the recent financial crisis (quantitative easing). See Brett W Fawley and Christopher J Neely, "Four Stories of Quantitative Easing," Federal Reserve Bank of St. Louis Review 95, no. 1 (2013).
} 
Against this background, in the European setting, one of the objectives of regulating shadow banking as part of the broader Action Plan on building a Capital Markets Union ${ }^{22}$ is to promote market finance and reduce the real economy's reliance on the banking sector, which is traditionally the dominant and primary medium of channeling funds from surplus spending units to deficit spending ones. In this context, shadow banking is viewed as a market-based finance and is often encouraged as it provides alternative sources of finance to the real economy and exerts a competitive pressure on the banking sector. ${ }^{23}$

The second important factor that plays a major role in distinguishing the European shadow banking from the US shadow banking is rooted in the structure of the banking industry or banking business models, which is embodied in the dichotomy of universal banking vs. separation of commercial and investment banking models in these two jurisdictions. If we define shadow banking as non-bank financial intermediation, ${ }^{24}$ in a universal banking model there is a wider scope for banks to engage in shadow banking activities. This means that in those jurisdictions where the dominant banking business model is universal banking, one would expect greater interconnectedness between banks and shadow banks. For example, in the universal banking model, since many financial activities can be performed under a single entity, it is more likely for the banking industry to engage in shadow banking operations through sponsoring MMFs, offering prime brokerages services, or through undertaking broker-dealer functions. ${ }^{25}$

This problem is especially acute in the bank sponsorship of MMFs in the EU, giving rise to higher levels of interconnectedness of the European MMFs to banks. ${ }^{26}$ Typically, MMFs are managed by asset management companies. Asset management companies are either sponsored by banks or run MMFs independently. In the euro area, more than $50 \%$ of large asset management companies are owned by banks or bank holding companies. ${ }^{27}$ Although roughly the same figures apply for the US MMFs,${ }^{28}$ it is estimated

\footnotetext{
${ }^{22}$ See Communication from the Commission to the European Parliament, the Council, and the European Economic and Social Committee and the Committee of the Regions Action Plan on Building a Capital Markets Union, COM/2015/0468 final.

${ }^{23}$ In addition to the regulatory efforts to encourage the market-based finance, shadow banking owes its growth to market forces, financial innovation, and technological developments. For an overview, see: André Prüm, In the Shadow of the Banks (Cowansville (Québec): Thomson Reuters, 2014), 15-18.

${ }^{24}$ For example, in FSB's view, the shadow banking system is a system of credit intermediation involving activities and institutions outside the traditional banking system. See Financial Stability Board, "Progress in the Implementation of the G20 Recommendations for Strengthening Financial Stability: Report of the Financial Stability Board to G20 Finance Ministers and Central Bank Governors," (2011).

${ }^{25}$ For how and why dealers are considered as part of the shadow banking system, see Zoltan Pozsar, "Shadow Banking: The Money View," Office of Financial Research Working Paper (2014).; See also Darrell Duffie, "The Failure Mechanics of Dealer Banks."; ${ }^{26}$ Elias Bengtsson, "Shadow Banking and Financial Stability: European Money Market Funds in the Global Financial Crisis," Journal of International Money and Finance 32 (2013).

${ }^{27} 10 \%$ of the asset management companies in the euro area are owned by insurance companies. See Nicola Doyle et al., "Shadow Banking in the Euro Area: Risks and Vulnerabilities in the Investment Fund Sector," ECB Occasional Paper Series, no. 174 (June 2016): 21.

${ }^{28}$ Jill E. Fisch, "The Broken Buck Stops Here: Embracing Sponsor Support in Money Market Fund Reform," North Carolina Law Review 93 (2014): 944.
} 
that 9 out of 10 biggest EU MMF managers are sponsored by commercial banks. ${ }^{29}$ As evidence suggests funds sponsored by banks with more MMFs under their sponsorship tend to take on more risk. ${ }^{30}$ This would result in a direct contagion channel between MMFs and sponsoring banks in the event of stress in the MMF industry.

\section{Shadow banking activities}

The specificities of the shadow banking system in the EU are also present in the financial activities typically associated with shadow banking. The differences are present in securities financing transactions (including repos (bilateral vs. tri-party repo) and securities lending ${ }^{31}$ ), securitization, and derivatives markets. ${ }^{32}$ One of the targets of regulation therefore was repo transactions, and the FSB, which champions the international initiatives for regulating shadow banking, issued recommendations regarding such transactions. A careful examination of the market structure and legal structure of the repo markets in the EU and the US reveals their foundational differences and raises doubts about whether a one-size-fits-all approach is the right path to take in regulating securities financing transactions. ${ }^{33} \mathrm{We}$ will discuss this issue in the next section.

\section{Securities financing transactions: What is special about the European markets?}

The largest European banks obtain collateral using Securities Financing Transactions (SFTs) rather than using derivatives. ${ }^{34}$ Repo transactions constitute the main type of SFTs in the EU, which makes it the main mechanism through which banks acquire short-term wholesale funding. ${ }^{35}$ The vulnerabilities in the wholesale funding and in particular short-term (overnight) repo markets were a significant source of

\footnotetext{
${ }^{29}$ European Commission, "New Rules for Money Market Funds Proposed - Frequently Asked Questions," (Brussles4 September 2013).

${ }^{30}$ Marcin Kacperczyk and Philipp Schnabl, "How Safe Are Money Market Funds?*," The Quarterly Journal of Economics 128, no. 3 (2013). For the concept of step-in risk and the approach that the BCBS has proposed to take on capital treatment of step-in risk, see Basel Committee on Banking Supervision, "Identification and Management of Step-in Risk - Second Consultative Document," (2017).

${ }^{31}$ In the securities lending, the lender passes the legal title of securities to the borrower for the life of the loan. When securities are returned to the lender, the lender again regains the title to the loan. During the lending period, even though the lender does not have legal title to the securities lent, the economic benefits of corporate actions (stock splits, income and dividends) will accrue to the lender. However, in case of equity securities, the lender will not retain voting rights of the securities it has lent for the duration of the term of the loan.

${ }^{32}$ Such difference also exists in trading venues, on which standardized derivatives must be traded, and clearing houses and central securities depositories through which those transactions must be cleared and settled. However, this is beyond the scope of this paper.

${ }^{3}$ See Wymeersch, "Shadow Banking and Systemic Risk," 19.

34 The data on collateral flows show that the at the beginning of 2013, the gross collateral flows (collateral posted and received) though repos amounted to $€ 5.8$ trillion, whereas collateral flows through derivatives stood at $€ 340$ billion. The total gross collateral flows stood at $€ 8.5$ trillion. 6. See Table 2 of Keller et al. (2014). See European Systemic Risk Board, "Esrb Opinion to Esma on Securities Financing Transactions and Leverage under Article 29 of the Sftr," (2016).

${ }^{35}$ Ibid., 7.
} 
systemic risk in the GFC. ${ }^{36}$. In addition to maturity and liquidity transformation, repo transactions allow for financial leverage with varying degrees depending on the level of haircut or initial margin. ${ }^{37}$ Since credit intermediation using repos is outside the government safety net, repos are vulnerable to runs and hence they lie at the heart of the fragility of the shadow banking system. ${ }^{38}$ The excessive dependence on short-term wholesale funding contributed to the spectacular collapse of some of the largest investment and commercial banks, such as Bear Stearns Companies, Inc., Lehman Brothers Holdings Inc., and Britain's Northern Rock. ${ }^{39}$ Given the importance of repos in the shadow banking system, it is of special importance to carefully examine the market structure as well as the legal structure of the repo markets across the Atlantic to highlight their fundamental differences and to bring such differences to the attention of the international regulatory fora.

In the wake of the GFC, the EU repo markets have undergone substantive transformation. For example, generally there has been a shift from unsecured funding to secured funding with the concomitant result of increasing importance of collateral in financial markets. ${ }^{40}$ According to the recent data by the FSB, the reliance of banks on short-term funding has increased on average in 16 jurisdictions. ${ }^{41}$ Bank assets funded by long-term wholesale assets decreased from $24 \%$ in 2011 to $23 \%$ in 2015 . This pattern has been steeper among the Other Financial Institutions (OFIs) whose reliance on long-term wholesale funding decreased from $28 \%$ of total assets to $22 \% .{ }^{42}$ In the same vein, the net repo positions of banks and OFIs has witnessed a spike. This means that the OFIs are net providers of cash to the financial system using repos. ${ }^{43}$ It seems that the reliance of financial institutions on non-bank repos is higher in the US, the FSB suggests that from among the 15 reporting jurisdictions, about $59 \%$ of non-bank repos are concentrated in the US in late $2015 .^{44}$ However, similar trends have been observed in the reliance of dealers on repo financing. Dealers' repo financing was at its peak in 2007 which constitutes $32 \%$ of their total liabilities. Since 2007, this figure has

\footnotetext{
${ }^{36}$ Gary B. Gorton and Andrew Metrick, "Securitized Banking and the Run on Repo," Journal of Financial Economics 104, no. 3 (2012).; Gorton, Slapped by the Invisible Hand: The Panic of 2007.

${ }^{37}$ Financial Stability Board, "Securities Lending and Repos: Market Overview and Financial Stability Issues- Interim Report of the Fsb Workstream on Securities Lending and Repos," (Basel, Switzerland2012), 8.

38 To see how government extended support to the shadow banking (especially broker dealers) and hence create new sets of government-backed shadow banking system, see Pozsar, "Shadow Banking: The Money View."

${ }^{39}$ Viktoria Baklanova, Adam Copeland, and Rebecca McCaughrin, "Reference Guide to Us Repo and Securities Lending Markets," in Federal Reserve Bank of New York Staff Reports (New York: Federal Reserve Bank of New York, 2015), 33-37.; The Financial Crisis Inquiry Commission, "The Financial Crisis Inquiry Report: Final Report of the National Commission on the Causes of the Financial and Economic Crisis in the United States," (Washington, D.C.2011); Arvind Krishnamurthy, Stefan Nagel, and Dmitry Orlov, "Sizing up Repo," The Journal of Finance 69, no. 6 (2014). Board, "Securities Lending and Repos: Market Overview and Financial Stability Issues- Interim Report of the Fsb Workstream on Securities Lending and Repos."

${ }^{40}$ Board, "Esrb Opinion to Esma on Securities Financing Transactions and Leverage under Article 29 of the Sftr," 7-8.

${ }^{41}$ Financial Stability Board, "Global Shadow Banking Monitoring Report 2016," (2017), 28.

42 Ibid.

${ }^{43}$ Ibid.

44 Ibid.
} 
declined and at the first quarter of 2015, it reached a low level of $13 \%$ of total liabilities. ${ }^{45}$ Dealers have also extended the maturity of their repo financing.

Despite serious efforts from the industry and self-regulatory organizations such as ICMA and SIFMA for standardization of repo transactions and harmonization of the applicable regime for repos, crossjurisdictional differences remain in place. ${ }^{46}$ There are at least three differences in the repo markets across the Atlantic. First, in Europe, a repurchase agreement transfers legal title to collateral from the seller to the buyer. In other words, a repo in Europe is a true sale; hence the name 'title transfer (financial) collateral arrangements' (TTCA). ${ }^{47}$ Whereas, in the US, under New York law, since transferring title to collateral is difficult, the collateral is pledged, however, it is exempt from certain provisions of the US Bankruptcy Code that apply to pledges (i.e., automatic stay). In this system, however, the pledgee or the buyer is given a general right of use of collateral, which is also known as rehypothecation. ${ }^{48}$ In spite of this legal nuance, this arrangement effectively - and in economic terms - is equivalent to an outright sale. One important crossjurisdictional distinction is that under the New York law, repos include a fall-back provision. Namely, if the buyer's right to collateral proves to be unenforceable, the repo will be recharacterized as secured lending. However, English law does not include such a provision.

Therefore, in the EU, in certain settings, it seems that there has been no need for bankruptcy safe harbors for repo transaction, because the right of reuse is inherent in the TTCA,${ }^{49}$ and such transactions were already concluded as a true sale transaction (title transfer) rather than a secured one. However, it seems that due to the differential treatments of such transactions in different Member States and potential conflicts stemming

\footnotetext{
${ }^{45}$ Baklanova, Copeland, and McCaughrin, "Reference Guide to Us Repo and Securities Lending Markets," 33-37. (See figure 13)

${ }^{46}$ Industry groups have developed two standard forms for master repurchase agreements. The Bond Market Association has published the Master Repurchase Agreement (1996) (The MRA) which is governed by the laws of the State of New York. The Global Master Repurchase Agreement (GMRA) (Version 1995) is published by Public Securities Association (PSA, a predecessor to the Bond Market Association that was the predecessor to Securities Industry and Financial Markets Association (SIFMA)) and the International Securities Market Association (ISMA, Now ICMA) and is governed by the laws of England. The first version of GMRA was published in 1992 and since then has undergone several substantial revisions resulting in 1995, 2000 , and 2011 versions. In addition, a Master Securities Loan Agreement (MSLA) of SIFMA in the U.S. is used for concluding securities lending transactions.

${ }^{47}$ In Europe, there are both "title transfer financial collateral arrangement" and "security financial collateral arrangement" (Art. 2 , Directive 2002/47/EC), but it seems that the majority of repos are in the form of TTCAs. For a difference between traditional collateralized lending and TTCA, see Joanna Benjamin, Guy Morton, and Michael Raffan, "The Future of Securities Financing," Law and Financial Markets Review 7, no. 1 (2013): 5-6.

${ }^{48}$ For the subtleties in the difference between the right of use and rehypothecation, see Financial Stability Board, "Transforming Shadow Banking into Resilient Market-Based Finance: Regulatory Framework for Haircuts on Non-Centrally Cleared Securities Financing Transactions," (Basel, Switzerland2015).

${ }^{49}$ Manmohan Singh, "Velocity of Pledged Collateral: Analysis and Implications," IMF Working Paper WP/11/256 (2011): 9.
} 
from such frictions, bankruptcy safe harbors are already included in the Settlement Finality Directive $(\mathrm{SFD})^{50}$ and the Financial Collateral Arrangements Directive. ${ }^{51}$

The second important difference in the repo markets across the Atlantic is that the US market is dominated by tri-party repo the maturity of which is often overnight. ${ }^{52}$ In a triparty repo market a third party (a repo agent) facilitates the repo settlement. Whereas a bilateral repo is directly settled between the two parties to the transactions (collateral and cash provider) without the interposition of a third party. ${ }^{53}$ The estimates reveal that two-third of the US repos are in the form of tri-party repos. In the EU, however, only $10 \%$ of the repos are triparty. ${ }^{54}$

The third difference manifests itself in the maturity of repo instruments in the EU and the US. The average maturity of US repo transactions is shorter than the maturity of such transactions in the EU. ${ }^{55}$ In June 2007, according to an ICMA survey, only $18.3 \%$ of the outstanding repos were overnight in Europe. As of June and December 2017, this figure stood at $18.4 \%$ and $16.9 \%$ respectively. ${ }^{56}$ However, the US repo market is largely overnight. ${ }^{57}$ This means that the maturity transformation happening through repo transactions in the US is higher than in the EU. Hence, ceteris paribus, the US repo markets are more likely to be prone to runs and are overall riskier than the EU repo markets. ${ }^{58}$

\footnotetext{
${ }^{50}$ Directive 98/26/EC of the European Parliament and of the Council of 19 May 1998 on settlement finality in payment and securities settlement systems, OJ L 166, 11.6.1998.

${ }^{51}$ Directive 2002/47/EC on financial collateral arrangements [2002] OJ L168/43, as amended by Directive 2009/44/EC [2009] OJ L146/37 and Directive 2014/59/EU [2014] OJ L173/190.

52 The maturity of the majority of triparty repos is overnight. See Adam Copeland et al., "Key Mechanics of the Us Tri-Party Repo Market," Federal Reserve Bank of New York Economic Policy Review 18, no. 3 (2012): 21. Most of those repos in the US are open (subject to rollover). See Viral V. Acharya and T. Sabri Öncü, "A Proposal for the Resolution of Systemically Important Assets and Liabilities: The Case Ofthe Repo Market," International Journal of Central Banking 9, no. S1 (2013): 310.

${ }^{53}$ Copeland et al., "Key Mechanics of the Us Tri-Party Repo Market."

${ }^{54}$ International Capital Market Association, "Frequently Asked Questions on Repo," ed. International Capital Market Association (ICMA) (2015).

There are also additional fundamental differences between the U.S and EU triparty repo markets. See ICMA FAQs, question no. 24.

${ }^{55}$ Krishnamurthy, Nagel, and Orlov, "Sizing up Repo," 29-30.

56 International Capital Market Association (ICMA), "European Repo Market Survey: Number 33 - Conducted June 2017," (October 2017).; "European Repo Market Survey," (March 2018).

${ }^{57}$ Association, "Frequently Asked Questions on Repo."

${ }^{58}$ The longer-term nature of repo markets in the EU might explain why repo constitute a higher proportion of the balance sheet of key market intermediaries in the EU. Ibid., Question no. 7 (What are the typical maturities of repos?)
} 


\section{Figure 2.14 - Maturity analysis (main survey)}

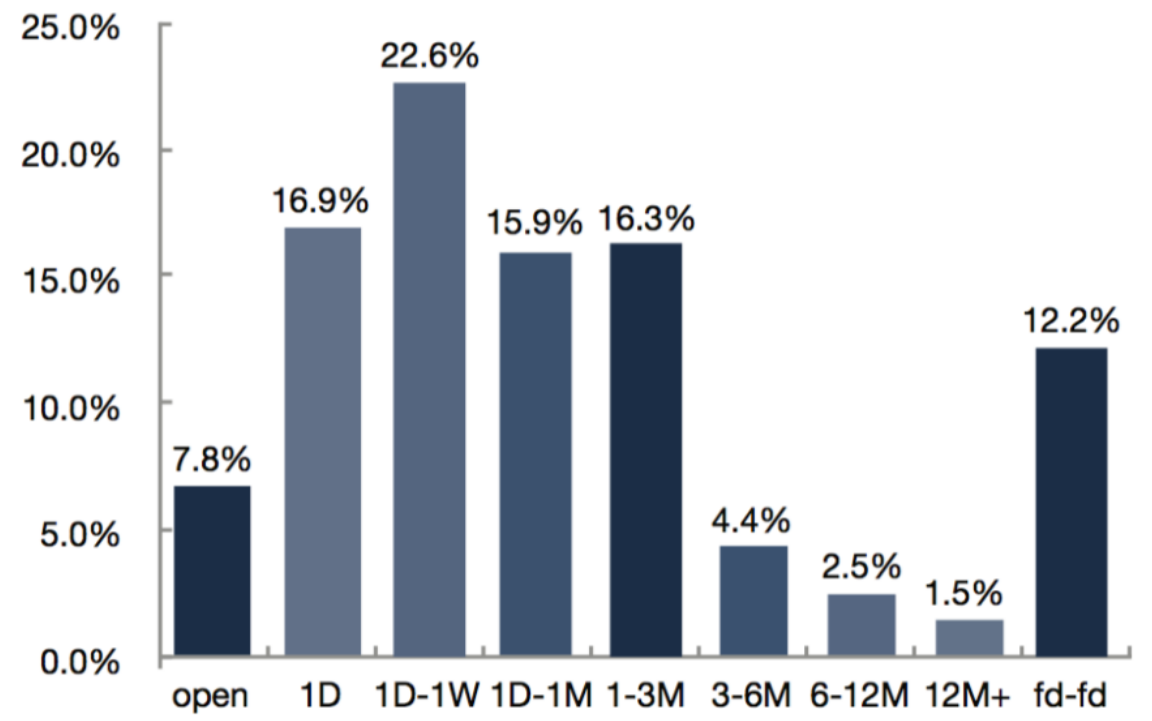

The fourth and perhaps one of the most important differences concerns the composition of the collateral used in the European repo markets. It is estimated that around $80 \%$ of the collateral used in the European repo markets is government securities. Structured securities used as collateral in the EU markets are a small portion of the overall collateral backing repo transactions, and where they are used, they are often used in tri-party repo markets. As stated above, tri-party repos amount to $10 \%$ of the European repo markets, and the use of structured securities as collateral amount to about $10 \%$ of the European tri-party repos. ${ }^{59}$

In general, jurisdictions where government bonds are prevalent as the collateral in repo are more likely to weather the times of repo market distress. ${ }^{60}$ Given that one of the reasons for the predominance of the repo transactions is the supply of highly-demanded safe assets, ${ }^{61}$ the use of government securities as collateral

\footnotetext{
59 Ibid.

${ }^{60}$ Financial Stability Board, "Global Shadow Banking Monitoring Report 2017," (Basel, Switzerland: Financial Stability Board, 5 March 2018).

${ }^{61}$ Gary B. Gorton and Andrew Metrick, "Regulating the Shadow Banking System," Brookings Papers on Economic Activity (2010).; "Securitized Banking and the Run on Repo."; For a different view, see Claudio Borio and Piti Disyatat, "Global Imbalances and the Financial Crisis: Link or No Link?," BiS Working Papers No 346 (2011),; Claudio Borio, "The Financial Cycle and Macroeconomics: What Have We Learnt?," Journal of Banking \& Finance 45 (2014).

For the concept of safe assets, see International Monetary Fund, "Global Financial Stability Report: The Quest for Lasting Stability," (Washington, DC: International Monetary Fund, April 2012), 81-122. See also, Anna Gelpern and Erik F. Gerding, "Rethinking the Law in "Safe Assets"," in Reconceptualising Global Finance and Its Regulation, ed. Ross P. Buckley, Emilios Avgouleas, and Douglas W. Arner (New York: Cambridge University Press, 2016).

Safe assets are described as "a variety of financial claims on public of private sector entities that are used as if they were risk-free." See ibid., 159.

Gorton et al. describe safe assets as "information-insensitive" or "immune to adverse selection in trading because agents have no desire to acquire private information about the current health of the issuer". See Gary Gorton, Stefan Lewellen, and Andrew Metrick, "The Safe-Asset Share," The American Economic Review 102, no. 3 (2012): 101.
} 
in the EU repo markets is of special importance for the financial stability, because these securities have proven to be resilient to runs in the times of crises. As the study by Gorton and Metrick on runs on repo backed by Asset-Backed Commercial Paper (ABCP) shows, during the financial crisis, the major repo runs occurred on the commercial paper (ABCP) used as collateral. ${ }^{62}$ Other studies show that such a run did not occur on repos backed by government bonds as collateral. ${ }^{63}$ Therefore, in the absence of sovereign default risk, the risk of a run on the European repo markets cannot be deemed significant. As the financial crisis also demonstrated, the EU repo markets weathered the crisis much better than the US markets, perhaps because of the reliance of the EU markets on repos collateralized by government bonds.

\section{Regulatory reforms of repo markets}

Regulatory reforms affecting the securities financing transactions - especially the collateral used in such transactions - span across a whole host of regulations having direct or indirect impact on such transactions. Rather counterintuitively, instead of the European regulation on transparency of securities financing transactions and of reuse (the SFTR regime), ${ }^{64}$ Basel III and its implementation in the EU by the Capital Requirements Directive (CRD IV) ${ }^{65}$ and the Capital Requirements Regulation (CRR) ${ }^{66}$ (jointly referred to as the CRD IV Package) have perhaps had the most dramatic impact on the repo markets. ${ }^{67}$ Risk-based capital requirements, leverage ratio, Liquidity Coverage Ratio (LCR) and Net Stable Funding Ratio (NSFR) all have a potential impact on repo markets in terms of increased cost of capital and liquidity for engaging in repo transactions. ${ }^{68}$ The impact is more dramatic in case of leverage ratio and LCR. ${ }^{69}$ For example, the LCR of Basel III makes it costlier for Bank Holding Companies (BHCs) and their subsidiaries to rely on short-term repo funding with low-quality collateral. Basel III NSFR is also adopted to encourage banks and

\footnotetext{
${ }^{62}$ Gorton \& Metrick focus on the commercial paper as the collateral used in the U.S. markets, which makes their study irrelevant for EU financial markets.; Gorton and Metrick, "Securitized Banking and the Run on Repo."; "Regulating the Shadow Banking System.".

${ }^{63}$ Shleifer and Krishnamurty suggest that the run only occurred on the repos with ABCP collateral, and not repos backed by government collateral. See Andrei Shleifer, "Comments and Discussions (Regulating the Shadow Banking System by Gary Gorton \& Andrew Metrick)," ibid.; Krishnamurthy, Nagel, and Orlov, "Sizing up Repo."

${ }^{64}$ Regulation (EU) 2015/2365 of the European Parliament and of the Council of 25 November 2015 on transparency of securities financing transactions and of reuse and amending Regulation (EU) No 648/2012, OJ L 337, 23.12.2015.

65 Directive 2013/36/EU of the European Parliament and of the Council of 26 June 2013 on access to the activity of credit institutions and the prudential supervision of credit institutions and investment firms, amending Directive 2002/87/EC and repealing Directives 2006/48/EC and 2006/49/EC; OJ L 176, 27.6.2013.

${ }^{66}$ Regulation (EU) No 575/2013 Of the European Parliament and of The Council of 26 June 2013 on prudential requirements for credit institutions and investment firms and amending Regulation (EU) No 648/2012, OJ L 176, 27.6.2013.

${ }^{67}$ Hossein Nabilou, "The Eu Framework for Bank Capital Regulation and Repo Collateral," SSRN Working Paper Series (2017).

${ }^{68}$ International Capital Markets Association, "Perspectives from the Eye of the Storm: The Current State and Future Evolution of the European Repo Market," (ICMA, 2015), 10.

${ }^{69}$ Ibid. For example, in addition, the calculations for the purpose of meeting the leverage ratio include leverage obtained through repo borrowing.
} 
their subsidiaries to rely more on longer-term liabilities and reduce their reliance on short-term wholesale funding. ${ }^{70}$

Recent studies have found that pursuant to the introduction of the supplementary leverage ratio (SLR) in 2012 in the US, repo borrowings by broker-dealer affiliates of $\mathrm{BHCs}^{71}$ has decreased, but the use of repo backed by more volatile collateral has increased. ${ }^{72}$ However, the evidence on this is far from conclusive. Some studies suggest risk shifting from broker-dealer affiliates of banks to those affiliated with non-banks and heightened amounts of risk due to the use of repos backed by more volatile collateral. ${ }^{73}$ In addition, there is evidence that broker-dealer affiliates of BHCs were discouraged from borrowing in triparty repo markets pursuant to the introduction of the leverage ratio. This development was concomitant with an increase in the activity of active nonbank-affiliated dealers in certain asset classes entering triparty repo markets, suggesting a risk shifting behavior from the banking sector to non-bank sector. ${ }^{74}$ This increase in the importance of nonbank-affiliated broker-dealers in tri-party repo markets has been due to the more stringent capital requirements imposed on BHCs at a consolidated level. ${ }^{75}$

Although the size of repo markets remains substantial, overall the maturity of repo funding has been extended, especially for the repos with low-quality collateral. There has also been a move toward diversification of funding sources among dealers. ${ }^{76}$ Although US dealers and banks have decreased their reliance on repo, for US-based foreign bank offices, repo remains a substantial source of funding. This is mainly because of differences in regulations as well as the fact that those banks have a limited access to US retail deposits. ${ }^{77}$

In 2011, the Federal Deposit Insurance Corporation (FDIC) expanded the deposit insurance assessment base from deposits to all of bank liabilities (including repos). This is expected to make it more expensive

\footnotetext{
${ }^{70}$ As a result of differentiated implementation of the Basel III in different jurisdictions, one might expect that divergence in the trend in the repo markets will be widened. Since in addition to Supplementary leverage ratio (SLR) in the US, there will be an enhanced supplementary leverage ratio (eSLR) for Global Systemically Important Banks (GSIBs). It seems that repo markets will be shaped differently across the Atlantic in response to the implementation of Basel III requirements.

${ }^{71}$ Major broker dealers in the US are a part of bank holding companies regulated by the Federal Reserve. For the complexities involved in the US bank holding structures, see Dafna Avraham, Patricia Selvaggi, and James Vickery, "A Structural View of Us Bank Holding Companies," FRBNY Economic Policy Review 18, no. 2 (2012).

${ }^{72}$ Meraj Allahrakha, Jill Cetina, and Benjamin Munyan, "Do Higher Capital Standards Always Reduce Bank Risk? The Impact of the Basel Leverage Ratio on the U.S. Triparty Repo Market," Office of Financial Research Working Paper (2016).

${ }^{73}$ Ibid.

${ }^{74}$ Ibid.

${ }^{75}$ Ibid., 33.

${ }^{76}$ For example, in December 2014, the top three dealers accounted for around 30 percent of the average daily volume in nontraditional triparty repo, down from nearly 50 percent in May 2010, when the Federal Reserve started publishing these statistics. See Federal Reserve Bank of New York, Tri-Party/GCF Repo, available at: https://www.newyorkfed.org/data-and-statistics/datavisualization/tri-party-repo/index.html. See also Baklanova, Copeland, and McCaughrin, "Reference Guide to Us Repo and Securities Lending Markets," 33-37.

77 Ibid.
} 
for insured banks to fund their assets in the repo markets. ${ }^{78}$ In addition, sections 165 and 166 of the DoddFrank Act (enhancing prudential standards for US BHCs) encourage the dealer subsidiaries of BHCs to shift more toward longer-term financing. Furthermore, the reforms of the market infrastructure for repo and derivatives transactions will also affect the repo markets. This is expected to strengthen the risk management by tri-party repo cash investors by incentivizing them to accept more liquid and high-quality collateral, hence decreasing the counterparty risk. A trend towards more conservatively collateralized triparty repo markets is expected which could lead to a more conservative pricing of credit intermediation by repo markets. ${ }^{79}$

\section{The case of rehypothecation}

One of the most controversial aspects of repo transactions is rehypothecation or reuse of collateral. ${ }^{80}$ Rehypothecation occurs when an intermediary holding securities on behalf of investors grants a security interest or encumbers those securities to obtain financing for itself. ${ }^{81}$ Rehypothecation is often practiced in the relationship between broker-dealers and their clients (risk portfolio managers or cash portfolio managers) and it provides an inexpensive source of financing for financial institutions, especially brokerdealers. ${ }^{82}$ For example, in repo financing, the broker-dealer often hypothecates the collateral provided by the risk portfolio manager (PM) so that it can procure financing for the risk PM from a cash PM in a matched-book method. ${ }^{83}$ Rehypothecation plays an important role in providing liquidity to markets. However, reuse of collateral is believed to pose risks to financial stability, particularly if one looks at how the global financial crisis manifested itself; namely, as withdrawals of collateral from investment banks such as Lehman Brothers. ${ }^{84}$

\footnotetext{
78 Ibid.

${ }^{79}$ Tobias Adrian and Adam B. Ashcraft, "Shadow Banking Regulation," Federal Reserve Bank of New York Staff Report, no. 559 (2012): 42.

${ }^{80}$ It appears that the term rehypothecation would be a confusing term in English law because its commercial use is different from its legal use. The word reuse could be a better and more precise term than rehypothecation. For more details, see Daniel Harris, "Use of Customer Securities by Uk Prime Brokers: The Road Ahead," Law and Financial Markets Review 7, no. 2 (2013). Reuse sometimes is also called repledge. For the difference between rehypothecation and reuse, see Singh, "Velocity of Pledged Collateral: Analysis and Implications," 9.

${ }^{81}$ Steven L. Schwarcz, "Distorting Legal Principles," Journal of Corporation Law 35, no. 4 (2010): 699.

${ }^{82}$ Christian A. Johnson, "Derivatives and Rehypothecation Failure: It's 3:00 Pm, Do You Know Where Your Collateral Is?," Arizona Law Review 30 (1997): 969.

83 See Pozsar, "Shadow Banking: The Money View."

${ }^{84}$ Duffie, "The Failure Mechanics of Dealer Banks."; Schwarcz, "Distorting Legal Principles," 700.; James Aitken and Manmohan Singh, Deleveraging after Lehman--Evidence from Reduced Rehypothecation (Epub), vol. 9 (International Monetary Fund, 2009). (showing that the after Lehman bankruptcy there was a significant reduction in rehypothecation by broker dealers. However, this reduced counterparty risk in the system came at the cost of having less liquid markets. Singh also finds that the decline in the source of pledgeable collateral and the subsequent reduction in the liquidity of the markets had an effect on the conduct of monetary policy.) See: Singh, "Velocity of Pledged Collateral: Analysis and Implications."
} 
The systemic risk concern originates from the uncertainty stemming from a decline in collateral prices and potential runs on the counterparties by the firms whose collateral is being rehypothecated. ${ }^{85}$ For example, the counterparty credit risk of prime brokers has always been a concern for hedge funds. At the center of such a concern is the reuse of collateral that hedge funds post to secure the funds they borrow from their prime brokers. Reusing collateral can increase the counterparty risk in times of financial distress during which uncertainty about the counterparty credit risks is in its height. ${ }^{86} \mathrm{It}$ is long established that aggregate uncertainty can impair the ability of the private sector to provide liquidity because this sector cannot be fully insured against the aggregate shocks ${ }^{87}$ Given that rehypothecation of assets can amplify uncertainty in financial markets, reuse of collateral may play a role in a liquidity crisis.

Rehypothecation of collateral is subject to regulation on both sides of the Atlantic. In the US, according to the section 724 of the Dodd-Frank Act, ${ }^{88}$ parties accepting money, securities or property to margin, guarantee, or secure a swap cleared by a derivatives clearing organization should register as Futures Commission Merchants (FCMs). The FCMs should treat all money, securities, and property of any swaps customer as belonging to the swap customer. They are also required to separately account for and not commingle the customer's funds with the funds of the FCM. In addition, section 724 requires segregation of assets for uncleared swaps. According to this requirement, a swap dealer or a Major Swap Participant (MSP) should notify the party wishing to enter a swap transaction at the beginning of the swap transaction that it has "the right to require the segregation of the funds or other property supplied to margin, guarantee, or secure the obligations of the counterparty." The aim of this provision is to prevent the swap dealer or an MSP from using customers' assets posted with them as collateral to be used as margin, guarantee, or as a security for any of its trades. ${ }^{89}$

In addition, in the US the rehypothecation or the reuse of collateral by the custodian or prime broker is capped at the $140 \%$ of the amount of debt of the client. In other words, the amount of a client's assets that can be rehypothecated by a prime broker or a broker dealer is capped to the equivalent of $140 \%$ of the

\footnotetext{
${ }^{85}$ Scott shows how hedge funds can face a prospect of becoming unsecured creditors under UK legal treatment of rehypothecated collaterals. See Hal Scott, "Interconnectedness and Contagion," Available at SSRN (2012): 76-79. In this context, a run by hedge funds on prime brokers might occur because of the uncertainty about the health of the prime brokerage firm when the prime broker has rehypothecated the collateral. Not knowing where the collateral initially posted by hedge funds to the prime broker is, distressed hedge funds might suddenly run to close their positions with that prime broker by grabbing and selling the collateral. This may cause serious distress to the prime broker.

${ }^{86}$ In this case, the counterparty does not know where the collateral is, who the right holder on that collateral is, and in case of default by the borrower, whether she can take the collateral or not. Such uncertainty can panic several right-holders in adverse economic conditions and may generate a run.

${ }^{87}$ Bengt Holmström and Jean Tirole, "Private and Public Supply of Liquidity," Journal of Political Economy 106, no. 1 (1998).

887 U.S.C $\$ 6 \mathrm{~d}$.

${ }^{89}$ Lloyd, Clancy and Kumar, Hedge Funds and Systemic Risk, pp. 77-79
} 
client's liability to the prime broker or dealer, ${ }^{90}$ but such a cap might not be needed under the UK securities financing transactions as discussed below. ${ }^{91}$

Financial collateral arrangements in Europe is governed mainly by the Directive 2002/47/EC on financial collateral arrangements, as amended (Financial Collateral Directive or FCD)..$^{92}$ The main aim of the FCD is to harmonize the regime applicable to financial collateral arrangements. The FCD governs the collateral provided using title transfer or the grant of a security interest. ${ }^{93}$ The main provisions include the prohibition of the recharacterization of title transfer as grant of security interests, ${ }^{94}$ right of use for collateral taker, ${ }^{95}$ a mechanism for rapid enforcements including close-out netting, ${ }^{96}$ and protections in insolvency (bankruptcy safe harbor). ${ }^{97}$ The FCD generally strengthens the position of collateral takers vis-à-vis collateral providers and creditors. Such a stance is based on the ground that providing such special treatment would improve market liquidity, lead to inexpensive credit and contribute to financial stability by preventing ripple effects originating from individual insolvencies.

At the EU level, on 23 December 2015, the European regulation on transparency of securities financing transactions and of reuse (SFTR) was published. ${ }^{98}$ This regulation contains measures aimed at increasing the transparency of the securities lending and repurchase agreements by mandating firms to report all such transactions to trade repositories. The SFTR is mainly concerned with the transparency of the SFTs, and reuse. Since it is believed that transparency helps increase market discipline and the effectiveness of the supervision, ${ }^{99}$ the SFTR strives to enhance the transparency of the SFTs through the following three mechanisms.

1. The transactions should be reported to a central database (except where one of the parties to the transaction is a central bank). This will help the supervisor to better identify the interconnectedness of banks and shadow banks.

2. The transparency on the practices of investment funds engaged in the SFTs and total return swaps

\footnotetext{
${ }^{90}$ Federal Reserve Regulation T (12 CFR §220) and SEC Rule 15c3-3.

${ }^{91}$ Manmohan Singh and James Aitken, "The (Sizable) Role of Rehypothecation in the Shadow Banking System," IMF Working Paper 10/172 (2010).

${ }^{92}$ Directive 2002/47/EC on financial collateral arrangements [2002] OJ L168/43, as amended by Directive 2009/44/EC [2009] OJ L146/37 and Directive 2014/59/EU [2014] OJ L173/190.

${ }^{93}$ For the distinction between the title transfer financial collateral arrangement and security financial collateral arrangement, see Directive 2002/47/EC, Art 2(1)(a), (b) and (c).

${ }^{94}$ Directive 2002/47/EC Art. 6

${ }^{95}$ Directive 2002/47/EC, Art. 5

${ }^{96}$ Directive 2002/47/EC, Arts. 4 and 7

${ }^{97}$ Directive 2002/47/EC, Art 8.

${ }^{98}$ Regulation (EU) 2015/2365 of the European Parliament and of the Council of 25 November 2015 on transparency of securities financing transactions and of reuse and amending Regulation (EU) No 648/2012, OJ L 337, 23.12.2015. (SFTR)

${ }^{99}$ For a different view of transparency in the banking sector and how it can be detrimental to the liquidity in debt markets, see Bengt Holmstrom, "Understanding the Role of Debt in the Financial System," BIS Working Paper No 479 (2015).
} 
will be improved by imposing reporting requirements on those operations.

3. The transparency of the reuse of collateral will be improved by imposing minimum conditions to be met for reuse, such as written agreement and prior consent. ${ }^{100}$

Therefore, the SFTR requires prior consent for reuse of collateral, and disclosure of risks and consequences of reuses to the parties posting the collateral. It subjects the right to reuse of collateral to the notice and consent requirements. ${ }^{101}$ In other words, the receiving counterparty should inform the counterparty providing the collateral in writing of the risks involved in consent to a right of reuses of collateral (according to Art. 5 of Directive 2002/47/EC) and in concluding a title transfer collateral arrangement, and the providing counterparty should grant its express consent to reuse. The establishment of reporting obligation to trade repositories, the new disclosure requirements for investments funds and reuse enhance the transparency of securities financing markets and will make detailed data available for regulators to monitor the risks of shadow banking.

One of the significant differences in the regulatory treatment of the securities financing transactions in the EU and the US is the limit or cap on the rehypothecation of collateral in the US as opposed to many other markets including the EU markets. At the EU level, there is no cap on the reuse, as opposed to the $140 \%$ cap in the U.S. ${ }^{102}$ However, individual member states such as France have similar limitations (140\% cap) in place. Although in the UK there is no $140 \%$ cap on rehypothecation, it seems that the percentage used in the US has created anchoring effect and in fact many hedge funds are using $140 \%$ cap as a benchmark in negotiating prime brokerage agreements with their banks. ${ }^{103}$

\section{Bankruptcy safe harbors for repo}

Another way to regulate repo is through the bankruptcy law applicable to the collateral used in repo, which turns out to be another controversial aspect of securities financing transactions and in particular repo. The run on repo, as one of the main contagion channels in the GFC, throwed the preferential treatment of repo collateral in bankruptcy into the spotlight once again. ${ }^{104}$ In the US, the collateral of repos and derivatives transactions (so-called Qualified Financial Contracts) is exempted from the automatic stay on the borrower's assets in case of bankruptcy. The Bankruptcy Code affords special treatment to derivatives contracts by exempting them from the 'automatic stay' and allowing counterparties to terminate these

\footnotetext{
${ }^{100}$ European Commission, "Regulation on Transparency of Securities Financing Transactions and of Reuse: Frequently Asked Questions," (Brussels29 October 2015).

101 Article 15 of the SFTR.

102 Autorité des Marchés Financiers (AMF), "The Reuse of Assets: Regulatory and Economic Issues," (November 9, 2016).

${ }^{103}$ Singh and Aitken, "The (Sizable) Role of Rehypothecation in the Shadow Banking System," 12.

${ }^{104}$ Gorton and Metrick, "Securitized Banking and the Run on Repo."
} 
contracts (by closing out, netting or setting off their derivatives positions) and to seize the underlying collateral. ${ }^{105}$ The repo transactions also enjoy equivalent protections.

Similar provisions exist in the EU. To mitigate the risk of a run on repo, the counterparties to a financial collateral arrangement (e.g., repos) are permitted to terminate the existing positions in the event of default. Such protection is intended to become as a 'firebreak' to contagion in the event of the failure of a large financial institution. ${ }^{106}$ Therefore, the underlying rationale for this safe harbor for derivatives and repos was that such markets can be a source of systemic risk and this exemption would be necessary to prevent the risks of contagion and systemic risk. ${ }^{107}$

Bankruptcy safe harbors for repos played an important role in the growth of shadow banking. ${ }^{108}$ However, after the GFC, these safe harbors have become highly controversial. It is argued that such protections fuel fire sales and collateral crises. ${ }^{109}$ In addition, the role of closeout and netting in reducing systemic risk is far from straightforward. ${ }^{110}$ In other words, although this exemption produces numerous benefits and is necessary for the well-functioning of financial markets, ${ }^{111}$ it facilitates or encourages the run on financial institutions by incentivizing counterparties of the banking entities to close-out or net derivatives contracts at the first signals of insolvency of a financial firm. Therefore, this safe harbor does not reduce systemic contagion, because it overlooks some intricate incentives lying in the interconnectedness of financial institutions. The safe harbors are also considered responsible for the failure of Lehman Brothers, especially accounting for the fact that the exemptions from the automatic stay failed to prevent a run on Lehman. ${ }^{12}$ For example, just before the collapse of Lehman brothers, JP Morgan seized \$17 billion in Lehman's collateral and demanded an additional $\$ 5$ billion payment. ${ }^{113}$

\footnotetext{
105 The Safe Harbor Provisions are embedded in the following provisions: 11 U.S.C. (2018) $\S 362$ (b)(6), 362(b)(7), 362(b)(17), 546, 556, 559, 560 \& 561 (2012). In Europe, such safe harbors are granted in the financial collateral directive. See: FCD, Art. 8. ${ }^{106}$ Directive 2002/47/EC on Financial Collateral Arrangements [2002] OJ L 168/43, as amended by Directive 2009/44/EC [2009] OJ L146/37. Recital 17.

107 See for example, René M. Stulz, "Should We Fear Derivatives?," The Journal of Economic Perspectives 18, no. 3 (2004): 188. 108 Gorton and Metrick, "Regulating the Shadow Banking System," 266.

${ }^{109}$ Carolyn Sissoko, "The Legal Foundations of Financial Collapse," Journal of Financial Economic Policy 2, no. 1 (2010). See also Steven L. Schwarcz, "Derivatives and Collateral: Balancing Remedies and Systemic Risk," University of Illinois Law Review 2015, no. 2 (2015).

${ }^{110}$ Robert R. Bliss and George G. Kaufman, "Derivatives and Systemic Risk: Netting, Collateral, and Closeout," Journal of Financial Stability 2, no. 1 (2006).

${ }^{111}$ For why the derivatives contracts should be treated differently on efficiency-based grounds, See Franklin R Edwards and Edward R Morrison, "Derivatives and the Bankruptcy Code: Why the Special Treatment," Yale Journal on Regulation 22 (2005).; See also Philipp Paech, "The Value of Insolvency Safe Harbours," LSE Legal Studies Working Paper No. 9/2015 (2015). (arguing that liquidity is the main value of such bankruptcy safe harbors).

112 Schwarcz, "Derivatives and Collateral: Balancing Remedies and Systemic Risk."

113 Duffie, "The Failure Mechanics of Dealer Banks." In addition, this safe harbor also encourages systemically risky market concentration on the conviction that on the default of a counterparty, the dealer would simply seize the collateral, making the dealer pay less attention to the amount of its concentrated exposure to one counterparty. See Schwarcz, "Derivatives and Collateral: Balancing Remedies and Systemic Risk."
} 
As it is clear, scholars are divided on a wide spectrum on this contested issue. Some believe that the safe harbors should be totally repealed. ${ }^{114}$ Others believe that they should be maintained in their entirety. ${ }^{115}$ And a third group believes in narrowing down the scope of such safe harbors. ${ }^{116}$ In general, removing the automatic stay exception would act as a curb on repos by reducing the liquidity of the collateral, particularly in tri-party markets. ${ }^{117}$ This could be a sensible regulatory measure to reduce the reliance on lower-quality collateral, akin to setting minimum haircuts. However, it would be probably unwarranted for higher-quality collateral, such as most government-guaranteed securities. ${ }^{118}$

There are various policy proposals for amending bankruptcy law as related to the repo transactions. Some proposals recommend the removal of the exemption from automatic stay for repos backed by risky or illiquid collateral. ${ }^{119}$ Others suggest making repos backed by risky or illiquid collateral subject to tax as a macroprudential tool, instead of removing the safe harbor. ${ }^{120}$ A rather distinct proposal comes from Acharya and Öncü who propose creating a special resolution authority called 'Repo Resolution Authority’ (RRA) for addressing the potential systemic risks of repo collateral fire sales during a financial crisis. ${ }^{121}$ They advocate the removal of the bankruptcy safe harbor, except for high quality government bonds. However, in the event of default by a counterparty on a repo, lenders should be able to sell the collateral to the PRA at market price less a predefined haircut specified by asset class by the PRA. The RRA would then make a liquidity payment to repo lenders and then would try to liquidate the collateral in an orderly manner. In this case, an ex-ante fee should be charged on repo lenders. Furthermore, there should also be certain eligibility

\footnotetext{
114 Stephen J Lubben, "Repeal the Safe Harbors," American Bankruptcy Institute Law Review 18 (2010).; "Derivatives and Bankruptcy: The Flawed Case for Special Treatment," University of Pennsylvania Journal of Business Law 12, no. 1 (2009).; "The Bankruptcy Code without Safe Harbors," American Bankruptcy Law Journal 84 (2010).; Charles W. Mooney, "The Bankruptcy Code's Safe Harbors for Settlement Payments and Securities Contracts: When Is Safe Too Safe?," Texas International Law Journal 49 (2014).

Antinolfi et al, also find that the bankruptcy safe harbors have contributed to the growth and development of repo markers, but also it might have increased the likelihood of fire sales and hence reduced the real investment in the economy. Therefore, bankruptcy policy makes face a trade-off between the reduction of the risk to the investment activities in the real economy and better liquidity of repo markets. See G. Antinolfi et al., "Repos, Fire Sales, and Bankruptcy Policy," Review of Economic Dynamics 18, no. 1 (2015). See also Sissoko, "The Legal Foundations of Financial Collapse." However, given the benefits of this safe harbor, it is argued that abolishing them would do more harm than good and it would adversely affect the liquidity of financial markets. See Nathan Goralnik, "Bankruptcy-Proof Finance and the Supply of Liquidity," Yale Law Journal 122 (2012).

115 "Bankruptcy-Proof Finance and the Supply of Liquidity."

${ }^{116}$ Bryan G. Faubus, "Narrowing the Bankruptcy Safe Harbor for Derivatives to Combat Systemic Risk," Duke Law Journal 59, no. 4 (2010). David Skeel and Thomas Jackson also explore the effects of transaction consistency or "equivalent treatment of similar transactions" in bankruptcy and conclude that imposing transaction consistency on repos would have limited impact. They also have a nuanced approach to removing safe harbors. See David A. Skeel and Thomas H. Jackson, "Transaction Consistency and the New Finance in Bankruptcy," Columbia Law Review 112, no. 1 (2012).

117 Goralnik, "Bankruptcy-Proof Finance and the Supply of Liquidity."

118 See Hossein Nabilou and Alessio Pacces, "The Law and Economics of Shadow Banking," in Research Handbook in Shadow Banking, ed. Iris H. Chiu (forthcoming 2017).

119 Darrell Duffie and David A Skeel, "A Dialogue on the Costs and Benefits of Automatic Stays for Derivatives and Repurchase Agreements," (2012).

${ }^{120}$ Enrico Perotti, "Systemic Liquidity Risk and Bankruptcy Exceptions," CEPR Policy Insight, no. 52 (2010).

121 Acharya and Öncü, "A Proposal for the Resolution of Systemically Important Assets and Liabilities: The Case Ofthe Repo Market."
} 
criteria on repo lenders. ${ }^{122}$ Other proposals put forward a recommendation to impose a temporary stay on close-out netting for a short period of time ( $48 \mathrm{~h}$ or until $5 \mathrm{pm}$ of the next business day). Such a temporary stay would allow for benefiting from the risk-mitigation advantage of close-out netting while preventing fire sales. However, any modification beyond that has not gained considerable traction. ${ }^{123}$

Recently, the Bank Recovery and Resolution Directive (BRRD) ${ }^{124}$ revised the regulatory treatment of the repo transactions and limited the exemption. As explained above, under the EU law of financial collateral arrangements, holders of instruments involving financial institutions whereby cash or securities are transferred by way of security are protected from the application of the insolvency laws or other measures that could hinder the enforcement of their close-out netting. ${ }^{125}$ Since such protections result in the erosion of the financial institutions goodwill, they were viewed as posing major challenges to insolvency procedures and successful resolutions. To address this problem, the FCD was revised by the BRRD to allow for a stay on close-out netting and enforcement provision for up to 48 hours. ${ }^{126}$ This new 48 -hour rule is intended to afford resolution authorities with adequate time for an orderly resolution. As of this writing, despite heated discussions and new proposals in the U.S., ${ }^{127}$ there has been no equivalent change in the bankruptcy framework of repos.

In the U.S., as a response to the concerns of run on repo giving rise to disorderly resolution of banks, the exemption from automatic stay no longer entirely applies to banks being taken over by the Federal Deposit Insurance Corporation (FDIC). ${ }^{128}$ Similarly, under the Dodd-Frank Act, counterparties to a 'covered financial company' ${ }^{129}$ may not be able to terminate contracts after the institution is put under the FDIC's

\footnotetext{
122 Ibid.

${ }^{123}$ Philipp Paech, "Shadow Banking: Legal Issues of Collateral Assets and Insolvency Law," (Brussels: European Parliament; Directorate General for Internal Policies; Policy Department A: Economics and Scientific Policy, 2013), 5. See also Skeel and Jackson, "Transaction Consistency and the New Finance in Bankruptcy."

Although Skeel and Jackson argue that the many of the bankruptcy safe harbors should be eliminated, they argue that there should still be automatic stay safe harbors for repos collateralized by cash like instruments (cash like collateral used in repo transactions.). See ibid., 156-57.

Other commentators believe that the safe harbors should be removed even for such instruments. See Norbert J. Michel, "Fixing the Regulatory Framework for Derivatives," (Washington, D.C.2016).

${ }^{124}$ Directive 2014/59/EU of the European Parliament and of the Council of 15 May 2014 establishing a framework for the recovery and resolution of credit institutions and investment firms and amending Council Directive 82/891/EEC, and Directives 2001/24/EC, 2002/47/EC, 2004/25/EC, 2005/56/EC, 2007/36/EC, 2011/35/EU, 2012/30/EU and 2013/36/EU, and Regulations (EU) No 1093/2010 and (EU) No 648/2012, of the European Parliament and of the Council, OJ L 173, 12.6.2014. (BRRD)

${ }^{125}$ Directive 2002/47/EC on Financial Collateral Arrangements [2002] OJ L 168/43, as amended by Directive 2009/44/EC [2009] OJ L146/37. Articles 2, 4.

126 See, BBRD, Arts. 70-71 and 118 that revises the FCD by inserting a new article 1(6) to that directive.

${ }^{127}$ For an overview of these proposals, see Jodie A Kirshner, "The Bankruptcy Safe Harbor in Light of Government Bailouts: Reifying the Significance of Bankruptcy as a Backstop to Financial Risk," NYUJ Legislation and Public Policy 18 (2015).

${ }^{128}$ For the operation of FDIC after receivership of the regulated bank, see Duffie and Skeel, "A Dialogue on the Costs and Benefits of Automatic Stays for Derivatives and Repurchase Agreements," 4. See also 12 U.S.C. (2018) § 1821 (e)(9), (10)(B), (13)(C)(i), which provides for a general prohobition to exercise certain contractual rights without consent.

${ }^{129}$ Defined in 12 U.S.C. (2018) § 5381(a)(8) which does not include insured depository institution.
} 
receivership. ${ }^{130}$ To address the issue of moral hazard, Dodd-Frank Act's section 214 further stipulates that taxpayers' funds cannot be used to prevent financial companies from liquidation, nor should they bear any losses in the liquidation process led by the authorities. ${ }^{131}$

\section{Shadow banking entities}

Shadow banking entities are composed of a complex web of financial entities, conduits, vehicles, and structures in different jurisdictions and are often masqueraded as a whole host of otherwise well-known institutions. Such institutions include MMFs, financial vehicle corporations (FVC; i.e., financial vehicles engaged in securitization), and other intermediaries such as securities dealers, hedge funds (and to a lesser degree venture capital funds), leasing and factoring companies and financial holding companies. Due to the limitation of the space, in this paper we only focus on MMFs as one of the most important components of the shadow banking system.

\section{MMFs in the EU}

MMFs are financial intermediaries that connect short-term debt issuers with providers of funds who need daily liquidity. In doing so, MMFs can become subject to runs due to their engagement in the liquidity transformation without access to government safety nets. In some European jurisdictions, investment funds can even originate loans that would entail credit intermediation risk. Bond funds investing in fixed income securities are potentially indirectly engaging in indirect credit intermediation and undertaking maturity and liquidity transformation. ${ }^{132}$ Therefore, as far as a fund engages in leveraged credit intermediation (liquidity and maturity transformation), they can impose externalities on other parts of the financial system. ${ }^{133}$ In addition, the risk of financial leverage exists in certain types of funds such as hedge funds. ${ }^{134}$ However, this paper only studies MMFs.

Unlike international initiatives, which propose certain policy objectives and regulatory approaches to addressing the potential systemic risks of the shadow banking sector, a closer examination of European MMFs shows that they display specific features that distinguish them from the US MMFs, and accordingly call for a rather nuanced regulatory approach. According to recent estimates by the European Systemic Risk Board (ESRB) and under the broad measure, which is based on the investment funds and OFIs, in the fourth

\footnotetext{
${ }^{130}$ See 12 U.S.C. (2018) § 5390 (e)(9), (b)(10)(B), (13)(C)(i); See also Duffie and Skeel, "A Dialogue on the Costs and Benefits of Automatic Stays for Derivatives and Repurchase Agreements.".

13112 U.S. Code $\$ 5394$ (a)(c).

${ }^{132}$ Laurent Grillet-Aubert et al., "Assessing Shadow Banking- Non-Bank Financial Intermediation in Europe," (Frankfurt am Main: European Systemic Risk Board, 2016), 12.

133 Ibid., 13.

134 Ibid., 12.
} 
quarter of 2015, the size of the shadow banking in the EU was around $€ 37$ trillion which amounted to $36 \%$ of the EU financial sector. ${ }^{135}$ This estimate stands at around $€ 28$ trillion for the Euro area. Between late 2012 and late 2015, the shadow banking system in the EU grew by $22 \%$. This is in sharp contrast to the size of the EU banking system which declined by $5 \%$ over the same period. As for the OFI sector, the euro area had the largest share of the total OFIs by the end-2015 with assets amounting to $\$ 30$ trillion. The US and the UK are the second and third largest jurisdictions with assets of $\$ 26$ trillion and $\$ 8$ trillion respectively. ${ }^{136}$

According to the ESRB's broad measure, the largest segment of the shadow banking system in the euro area is the investment fund sector. MMFs in the EU amount to $€ 1.1$ trillion and non-MMFs amounting to $€ 10.3$ trillion. Financial vehicle corporations (FVCs) also stand at $€ 1.8$ trillion of the broad measure and non-securitization Special Purpose Entities (SPEs) amount to $€ 3.7$ trillion. 39\% of the broad measure is categorized as other OFIs that constituting $€ 10.8$ trillion composed of heterogeneous entities not covered by regular data collection. ${ }^{137}$ OFIs engaging in the shadow banking activities display a significant heterogeneity ${ }^{138}$ and the data about them are largely lacking. This particularly applies to non-securitization SPEs and holding companies, financial corporations engaged in lending, and securities and derivative dealers. ${ }^{139}$

The most significant difference between the US and the EU MMFs is in the market structure and composition of the MMFs. First, the EU has a very small MMF sector that belongs to a heavily regulated investment fund industry. The total assets under management (AUM) of the EU MMFs roughly amounts to $€ 1$ trillion, standing at around $15 \%$ of the European fund industry. ${ }^{140}$ In the euro area, the balance sheets of the MMFs only represent $4 \%$ of the MFIs' balance sheets, credit institutions (banks) constitute $96 \%$ of the balance sheets of the MFIs. ${ }^{141}$ Therefore, EU MMFs do not appear to be systemic because of their size.

Second, in most European jurisdictions, such as in Belgium. France, Germany, Italy, the Netherlands,

\footnotetext{
${ }^{135}$ Ibid., 9. It is necessary to mention that almost all data about the shadow banking suffers from certain inconsistencies. This is because the data about the shadow banking activities, entities and instruments are hard to come by. The difficulty in obtaining the data is partly due to the ambiguity about the definition of shadow banking and partly due to the fact that different components of shadow banking perform different functions in the economy and are so interconnected to the traditional banking and other parts of the economy that makes it virtually impossible to disentangle and identity the pure shadow banking activities, entities or instruments. Indeed, there is no such aggregate data about shadow banking as there is on for example, flow of funds. See Pozsar, "Shadow Banking: The Money View."

136 Board, "Global Shadow Banking Monitoring Report 2016," 17.

${ }^{137}$ Grillet-Aubert et al., "Assessing Shadow Banking- Non-Bank Financial Intermediation in Europe," 10.

138 Ibid., 11.

${ }^{139}$ Ibid.

${ }^{140}$ Commission, "New Rules for Money Market Funds Proposed - Frequently Asked Questions."

${ }^{141}$ Klára Bakk-Simon et al., "Shadow Banking in the Euro Area: An Overview," ECB Occasional Paper Series No 133 (2012): 16.
} 
Switzerland, and the UK, Variable Net Asset Value (VNAV) structures are prevalent. ${ }^{142}$ Therefore, the majority of EU MMFs are VNAV funds which form one of the most striking differences of the EU MMFs from their US counterparts. It is estimated that $60 \%$ of the EU MMFs are VNAV funds and only $40 \%$ are in the form of CNAV model. ${ }^{143}$ As a VNAV MMF is not a suitable substitute to a bank deposit and as it is not subject to maturity mismatch and liquidity risks, they cannot even be considered a part of the shadow banking system. Overall, this marks a major distinction between the EU and US MMFs in the sense that the EU MMFs are less likely to engage in liquidity and maturity transformation, and even if they are exposed to maturity and liquidity mismatch risk, it is less likely for them to become systemically relevant due to their size. The relative resilience of the European MMFs during the crisis confirms this proposition.

An additional problem in the MMF sector relates to the sponsor support, which raises concerns about interconnectedness. The main problem in the interconnectedness of MMFs with banks is associated with CNAV funds. The promise of on-demand redemption at a stable share price (i.e., on-demand par-value redemption promise) bears substantial resemblance to the promise made by banks in taking deposits. Indeed, a CNAV MMF can functionally be an alternative to a bank deposit especially for investment funds and corporate treasurers with sizable amounts of cash under their management. To sustain the promise of on-demand par-value redemption, CNAV MMFs have traditionally relied on their sponsor (often a bank) for discretionary capital.

Sponsor rescue may take many forms such as capital support agreements, letters of credit (guarantees), management fee waivers or distressed asset purchases at amortized costs. The sponsor support is often purely discretionary, i.e., there is no legal obligation on the side of the sponsor to allocate certain levels of funds or liquidity for stabilizing the sponsored MMF under liquidity stress. ${ }^{144}$ However, to avoid potential reputational risks of the failure of the sponsored fund, the sponsoring bank often supports the ailing sponsored fund by extending credit lines, liquidity support or indemnification in times of crisis. ${ }^{145}$

Studies suggest that during the GFC, at lease 21 MMFs would have broken the buck had there been no sponsor support. ${ }^{146}$ Indeed, between 2007 and 2011, in 123 instances, out of a total of 341 MMFs, 78 funds

\footnotetext{
142 Board, "Global Shadow Banking Monitoring Report 2016," 22.

${ }^{143}$ European Commission, "Consultation Document; Undertakings for Collective Investment in Transferable Securities (Ucits): Product Rules, Liquidity Management, Depositary, Money Market Funds, Long-Term Investments," (Brussels2012), 13.

${ }^{144}$ For more details, see Fisch, "The Broken Buck Stops Here: Embracing Sponsor Support in Money Market Fund Reform.". Though regarding capital requirements, there is a special regime that applies to such commitments.

${ }^{145}$ This risk is also known as step-in risk. For the concept of step-in risk and the approach that the BCBS has proposed to take on capital treatment of step-in risk, see Supervision, "Identification and Management of Step-in Risk - Second Consultative Document." The Dodd-Frank has certain rules on this. (sharing the brand name, etc.). See Doyle et al., "Shadow Banking in the Euro Area: Risks and Vulnerabilities in the Investment Fund Sector," 21.

${ }^{146}$ Steffanie A Brady, Ken E Anadu, and Nathaniel R Cooper, "The Stability of Prime Money Market Mutual Funds: Sponsor Support from 2007 to 2011," Federal Reserve Bank of Boston Risk and Policy Analysis Unit Working Paper RPA 12-3 (2012).
} 
received sponsor support amounting to at least $\$ 4.4$ billion. ${ }^{147}$ In Europe, during the GFC, the prominent examples of sponsor support was the asset purchase by Société Général and Credit Suisse from their MMFs, and Barclays’ extension of guarantees costing $£ 276$ million. ${ }^{148}$ As the below figure suggests, such discretionary sponsor support is not a phenomenon of the crisis, but it has been prevalent even before the GFC. ${ }^{149}$ Although since the adoption of Securities and Exchange Commission (SEC) rules on MMFs in 1983 there has only been two instances of MMFs breaking the buck (the Community Bankers US government Fund in 1994, and the Reserve Primary Fund in 2008), in the absence of sponsor support, there would have been many MMFs breaking the buck. ${ }^{150}$

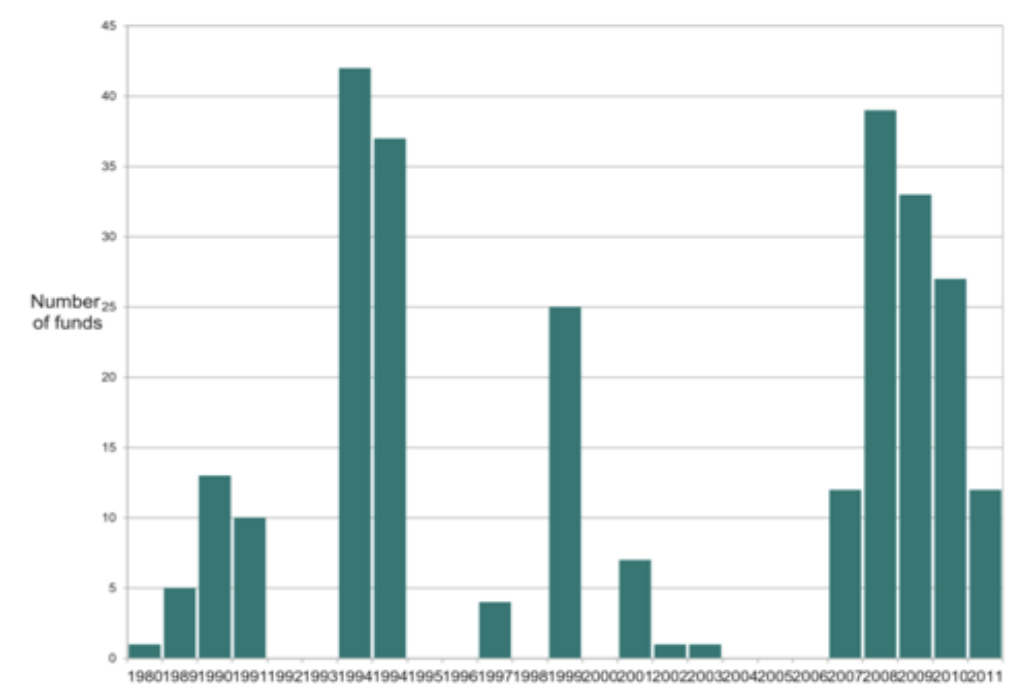

Fig. 1. Number of funds receiving support: 1980-2011. Data sources are Brady, Anadu and Cooper (2012).

The liquidity support by the sponsor to the distressed MMF can expose the sponsoring bank to liquidity risks. This increases the probability of the failure of the sponsoring bank. To counter this problem the EU MMF regulation ${ }^{151}$ prohibits the sponsor support altogether. ${ }^{152}$ The US regulator, however, has taken a different approach as it allows discretionary support, but imposes transparency requirements for such support. The outright prohibition on discretionary sponsor support is criticized on the grounds that without such a support the par-value on-demand redemption promise would be nearly impossible, making the

\footnotetext{
147 Ibid.

148 Bengtsson, "Shadow Banking and Financial Stability: European Money Market Funds in the Global Financial Crisis."

149 Brady, Anadu, and Cooper, "The Stability of Prime Money Market Mutual Funds: Sponsor Support from 2007 to $2011 . "$ See also: Cecilia Parlatore, "Fragility in Money Market Funds: Sponsor Support and Regulation," Journal of Financial Economics 121, no. 3 (2016): 596.

${ }^{150}$ Brady, Anadu, and Cooper, "The Stability of Prime Money Market Mutual Funds: Sponsor Support from 2007 to $2011 . "$

${ }^{151}$ Regulation (EU) 2017/1131 of the European Parliament and of the Council of 14 June 2017 on money market funds $O J$ L 169 , 30.6.2017. (Hereinafter, EU MMFs Regulation)

${ }^{152}$ Art. 35 of the EU MMF Regulation.
} 
CNAV fund model unsuitable for liquidity management for institutional investors. ${ }^{153}$ On the contrary, such critics argue for the formalization of the sponsor support; a form of transparent mandatory sponsor support rather than a discretionary one. ${ }^{154}$

In addition to the sponsor support, to address the liquidity issues of MMFs, the EU proposal for the regulation of MMFs required the CNAV MMFs (and not the sponsoring bank) to maintain a cash reserve (the so-called 'NAV Buffer') of $3 \%$ of the fund's assets under management (AUM). ${ }^{155}$ This was expected to reduce the likelihood of the liquidity crisis in a CNAV fund and hence of the actual liquidity support by the sponsoring bank. However, after staunch resistance from the industry and market participants, this proposal was withdrawn. Eventually, instead of cash reserve requirement, ${ }^{156}$ the EU MMF regulation tilted towards imposing portfolio restrictions on the CNAV funds.

The interconnectedness of banks to MMFs is not a one-sided phenomenon. In addition to banks' investment in MMFs, ${ }^{157}$ MMFs are a source of short-term financing for financial institutions. It is estimated that around $40 \%$ of short-term debt issued by the banking sector is held by MMFs. ${ }^{158}$ Moreover, there is an additional international aspect to the interconnectedness of banks and MMFs. Estimates show that the US MMFs supply sizable funding to the EU banks, making them vulnerable to the shocks originating from the US MMFs. ${ }^{159}$

Another source of systemic risk that might arise from the MMFs is the level of concentration in the asset management industry. Data show that as of Q3 2015, 84.9\% of all assets are managed by $10 \%$ of the asset management companies in the euro area. ${ }^{160}$ In addition, the $90 \%$ of all AUM is managed by the 130 largest asset management companies. The 25 largest asset managers, many of whom owned by banking groups, represent $53 \%$ of total net assets and 33\% of funds. ${ }^{161}$ There is an additional concern about geographic concentration in Europe. More than $90 \%$ of the AUM is managed from a few countries such as

\footnotetext{
${ }^{153}$ Fisch, "The Broken Buck Stops Here: Embracing Sponsor Support in Money Market Fund Reform."

${ }^{154}$ Ibid.

155 Art. 30 of the Proposal for a REGULATION OF THE EUROPEAN PARLIAMENT AND OF THE COUNCIL on Money Market Funds/* COM/2013/0615 final - 2013/0306 (COD).

156 This requirement is also known as capital requirements, however, in the authors' view, it could best be described as (cash) reserve requirements.

${ }^{157}$ European Central Bank, "Report on Financial Structures," (October 2015).; "Report on Financial Structures," (Frankfurt am Main2016).; "Report on Financial Structures," (Frankfurt am Main2017).

158 Commission, "New Rules for Money Market Funds Proposed - Frequently Asked Questions." See also Bank, "Report on Financial Structures."

159 Bank of England, "Financial Stability Report," (London2011). The dependence of the EU banking sector on US dollardenominated funding from MMFs was also emphasized by the public recommendation published in January 2012 by the European Systemic Risk Board (ESRB). See European Systemic Risk Board, "Recommendation of the Esrb of 22 December 2011 on Us Dollar Denominated Funding of Credit Institutions (Esrb/2011/2)," (2011).

${ }^{160}$ Doyle et al., "Shadow Banking in the Euro Area: Risks and Vulnerabilities in the Investment Fund Sector," 20.

161 Ibid., 21.
} 
Luxembourg, Germany, Ireland, the UK, France and the Netherlands. ${ }^{162}$ By the same token, there is a significant disparity across the euro area countries in terms of their contribution to the financial intermediation. For example, in Luxembourg, the MMFs represent 27\% of the total balance sheet of MFIs. This number stand at $24 \%$ in Ireland. ${ }^{163}$

Even inside the EU, there is a significant level of heterogeneity in the shadow banking entities. ${ }^{164}$ This diversity is especially pronounced in the investment fund sector to which the MMFs belong, and it is to such a degree that makes it difficult to include substantial portion of this sector in shadow banking without further painstakingly elaborate classifications. Studies by the ESRB shows substantial heterogeneity in how differently banks and investment fund sector engage in credit intermediation, and liquidity and maturity transformation. For example, a majority of hedge funds acquire leverage using derivatives (i.e., synthetic leverage) and their reliance on unsecured debt is minimal. Leverage in investment funds is either on an overnight basis or is withdrawable on demand making them subject to runs. According to the ESRB, the existing measures of leverage do not capture the synthetic leverage. ${ }^{165}$ Overall, the main criterion for considering investment funds as shadow banks lies in their vulnerability to runs originating from maturity and liquidity mismatch and the lack of official safety nets. ${ }^{166}$ Regulating shadow banking entities as regards the investment fund sector mainly targets MMFs and OFIs. In what follows we study the regulatory regime for MMFs.

\section{MMF regulation in the $\mathrm{EU}$}

In 2013, the European Commission presented its proposal for a new MMF regulation, which was adopted in 2017 by the Parliament and the Council. ${ }^{167}$ Contrary to the early suggestions, the regulation does not ban the CNAV model. However, the treatment of the CNAV MMFs has been proved to be the most contentious issue in the proposal. The proposal contained other controversial issues such as limits on external support and the admissibility of investment in other MMFs. In brief, the most important difference between the proposal and the regulation is that the final regulation does not contain any reserve requirement for the MMFs.

\footnotetext{
162 Grillet-Aubert et al., "Assessing Shadow Banking- Non-Bank Financial Intermediation in Europe," 11-12.

${ }^{163}$ Bakk-Simon et al., "Shadow Banking in the Euro Area: An Overview," 16.

${ }^{164}$ Ibid., 15-16.

165 Grillet-Aubert et al., "Assessing Shadow Banking- Non-Bank Financial Intermediation in Europe," 16.

${ }^{166}$ Financial Stability Board, "Global Shadow Banking Monitoring Report 2015," (Basel2015).

${ }^{167}$ Regulation (EU) 2017/1131 of the European Parliament and of the Council of 14 June 2017 on money market funds OJ L 169, 30.6.2017, p. 8-45, (EU MMFs Regulation)
} 
The EU MMF Regulation recognizes three different types of MMFs. VNAV MMFs, public debt CNAV MMFs and Low volatility NAV MMFs (LVNAV MMFs). ${ }^{168}$ This regulation imposes certain levels of daily/weekly liquidity (portfolio rules) on both short-term MMFs ${ }^{169}$ and standard MMFs. ${ }^{170}$ The LNAV and public debt CNAV funds are required to hold at least $10 \%$ of their assets in instruments that mature on a daily basis ${ }^{171}$ and an additional $30 \%$ of their assets maturing in a week. ${ }^{172}$ These liquidity requirements are imposed to ensure that investor redemption could be satisfied in a timely fashion.

The regulation further imposes a requirement, which has come to be known as 'clear labelling' on whether the fund is a short-term MMF (holding assets with residual maturity not exceeding 397 days) or a standard MMF (holding assets with residual maturity not exceeding 2 years). ${ }^{173}$ The regulation further requires MMFs to use customer profiling policies or the so-called 'know your customer policies' in order to help the fund to anticipate large redemptions. ${ }^{174}$ The regulation also requires MMFs to use certain internal credit risk assessment by the MMF managers, ${ }^{175}$ which is devised to discourage MMF to over-rely on external ratings. In addition, the regulation imposes certain limitations on exposures to a single counterparty and it introduces diversification requirements, ${ }^{176}$ concentration limits, ${ }^{177}$ stress testing requirements, ${ }^{178}$ and more importantly it prohibits CNAVs funds from receiving any other external form of support. ${ }^{179}$

The proposal for EU regulation contained a cash reserve cushion of 3\% for CNAV funds (the so-called 'NAV buffer'). ${ }^{180}$ This buffer could be activated to address the redemptions in times of stress. It could operate similar to a buffer to enable the fund to adjust the difference between the CNAV of $€ 1$ and the price fluctuations of the underlying portfolio. ${ }^{181}$ This requirement turned out to be the most contentious aspect of the proposal. As mentioned earlier, however, it was dropped in the legislative process and could not see the light of day.

\footnotetext{
168 Art. 3 of the EU MMFs Regulation.

${ }^{169}$ Art. 24 of the EU MMFs Regulation.

170 Art. 25 of the EU MMFs Regulation.

171 Art. 24 (c) of the EU MMFs Regulation.

172 Art. 24 (e) of the EU MMFs Regulation.

173 Recitals 39 \& 40 and articles 2(14) \& (15) \& article 24 and 25 of the EU MMFs Regulation.

174 Art. 27 of the EU MMFs Regulation.

175 Arts. 19 \& 20 of the EU MMFs Regulation.

176 Art. 17 of the EU MMFs Regulation.

177 Art. 18 of the EU MMFs Regulation.

178 Art. 28 of the EU MMFs Regulation.

${ }^{179}$ Art. 35 of EU MMFs regulation

180 Art. 30 of the Proposal for a REGULATION OF THE EUROPEAN PARLIAMENT AND OF THE COUNCIL on Money Market Funds/* COM/2013/0615 final - 2013/0306 (COD).

${ }^{181}$ Commission, "New Rules for Money Market Funds Proposed - Frequently Asked Questions."
} 


\section{MMF regulation in the US}

Starting from the 1970s, in the US, financial products developed by the MMFs, called NOW accounts (Negotiable Order of Withdrawal), were widely accepted as a direct substitute to bank deposits. These were the early examples of shadow banking instruments disintermediating the banking entities. ${ }^{182}$ As of now, US MMFs represent more than 50\% of global MMFs, ${ }^{183}$ and CNAV MMFs are effective substitutes for insured deposits, and provide continuous liquidity for those institutional investors that have surplus funds and need daily liquidity. However, the involvement of the MMFs, specifically the Reserve Primary in the GFC, which resulted in its liquidation, was one of the reasons that drew attention to the risks of runs on MMFs and triggered their regulatory reform proposals.

The SEC and the Office of the Comptroller of the Currency (OCC) have adopted measures on the reform of the MMFs and short-term investment funds (STIFs) to address risk of runs. SEC's 2014 revisions to the regime governing MMFs, ${ }^{184}$ have so far focused on reducing risks on the asset side of MMFs' balance sheet. These reforms require a minimum percentage of assets to be held in highly liquid securities (daily and weekly requirements), they further impose restrictions on the purchase of lower quality securities by MMFs.

According to the SEC rules, there will be three different categories of MMFs: retail (prime/municipal) MMFs, institutional (prime/municipal) MMFs, and government MMFs. Retail (prime/municipal) MMFs will be priced daily at CNAV of $\$ 1.00$, and they will be available to natural persons only. Institutions, businesses, and other organizations are not eligible to invest in these types of funds. ${ }^{185}$ They are required to impose liquidity fees and/or redemption gates. Institutional (prime/municipal) MMFs will be priced daily at VNAV. All categories of investors are eligible to invest in these types of funds. They are required to impose liquidity fees or redemption gates. And finally, government MMFs that will be priced daily at CNAV, and there will be no restrictions on eligible investors. These MMFs can impose redemption or liquidity fees and/or they can suspend redemption (aka redemption gates). ${ }^{186}$ Although these reforms may protect investors, they are assessed as unlikely to address the risk of runs on MMFs. ${ }^{187}$

In addition, the SEC rules treat government MMFs (that invest at least $80 \%$ of their assets in US government debt) and prime MMFs (that invest in corporate debt) differently. According to these rules, government

\footnotetext{
182 Morgan Ricks, The Money Problem: Rethinking Financial Regulation (Chicago: University of Chicago Press, 2016).

${ }^{183}$ Board, "Global Shadow Banking Monitoring Report 2016," 21.

${ }^{184}$ Money Market Fund Reform; Amendments to Form PF, 79 Fed. Reg. 47,736, 47,736 (Aug. 4, 2014) (to be codified at 17 C.F.R. pts. 230, 239, 270, 274, 279) [See 17 CFR 270.2a-7]; Financial Stability Oversight Council, "Financial Stability Oversight Council (Fsoc) 2016 Annual Report," (Washington, D.C.: Financial Stability Oversight Council, 2016), 111-12.

${ }^{185}$ For a critique of this classification and restrictions, see Fisch, "The Broken Buck Stops Here: Embracing Sponsor Support in Money Market Fund Reform."

${ }^{186}$ Retail funds will be available only to natural persons (individuals, certain trusts and retirement accounts).

${ }^{187}$ Adrian and Ashcraft, "Shadow Banking Regulation," 45.
} 
MMFs can maintain stable price per share (CNAV), but the prime MMFs should adopt the VNAV pricing model. Therefore, the US does not report the MMFs based on CNAV and VNAV classification. In other words, in the US, there are two types of major MMFs: government-only MMFs and prime MMFs. ${ }^{188}$ Government-only MMFs primarily invest in government securities, tax-exempt municipal securities, or corporate debt securities, while prime MMFs invest both in government securities and in corporate securities. ${ }^{189}$

Due to the differences in the market structure, there are differences in the regulation of the MMFs in the EU and the US. As mentioned before, in Europe, there was no regulatory or statutory classification of funds based on the portfolio of their investments (government vs. prime funds), instead, the classification relied on the fact that whether MMFs were short-term MMFs and standard MMFs. In other words, the US regulation differs from the EU regulation in that it differentiates between government MMFs (with investment of at least $80 \%$ of their assets in US government debt) and prime MMFs that primarily invest in corporate debt. MMFs investing primarily in the US government debt can maintain CNAV model and prime MMFs should adopt VNAV pricing model. ${ }^{190}$

The EU largely follows the same classification, though introducing a new classification of LVNAV funds. In the EU, euro or sterling denominated government MMFs are very small (approximately $3 \%$ of assets managed in the CNAV model). ${ }^{191}$ Putting this next to the fact that VNAV model is prevalent in the EU, one would conclude that the likelihood of runs on EU MMFs is lower as they do not promise at-par on-demand redemptions. Despite this, the EU regulation is very similar to the US rules governing the MMFs (SEC Rule 2a-7) on liquidity rules, issuer diversification and customer profiling. Such similarity may come as a surprise as EU MMFs historically have developed as VNAV funds that do not pose financial stability risks; CNAV funds have not been popular in the EU and those are the exact same funds that may pose systemic risks. In MMFs, however, the main point of divergence remains to be the regime applicable to the external sponsor support. In the EU, such a support is completely banned, while in the US, it is allowed, but subject to certain regulatory requirement such as transparency rules.

\footnotetext{
188 Pozsar, "Shadow Banking: The Money View."

189 U.S. Securities and Exchange Commission, SEC Spotlight: Money Market Funds, last modified: Nov. 3, 2016. https://www.sec.gov/spotlight/money-market.shtml

190 The new EU money market fund regulation converges with that of the US in that it introduces public debt MMFs.

${ }^{191}$ The so-called government MMFs in Europe (those investing in Euro or sterling-denominated government bonds) are very small (amounting to roughly $3 \%$ of assets managed under the CNAV model), therefore, the regulator decided to require the European CNAVs to hold capital to back up at-par redemptions. See Commission, "New Rules for Money Market Funds Proposed Frequently Asked Questions."
} 


\section{Summary and conclusion}

In this article, we argue against one-size-fits-all policy prescriptions for addressing the risks of the shadow banking system. Focusing primarily on the EU shadow banking system and contrasting it with that of the US, we have demonstrated that not only did shadow banking evolve very differently worldwide, but also it substantially differs across jurisdictions in the developed world. A closer examination of the financial instruments, activities and entities of shadow banking reveals that the deeper structural differences in the EU and the US banking and shadow banking are at the roots of the differences in the development of the shadow banking sector across the Atlantic. The traditional bank-based financial system in Europe and its reliance on the universal-banking business model has given rise to idiosyncratic shadow banking structures in the EU, which is significantly different from the US model of shadow banking.

Regarding the securities financing transactions, as a major segment of shadow banking activities, despite the international efforts to harmonize such transactions at the micro level (e.g., contract design and bankruptcy protections), at the macro level, the markets for securities financing transactions remain fragmented across the Atlantic. First, while in the US the main mechanism used for securities financing transactions is the security financial collateral arrangement, in the EU, it is more likely that a title transfer financial collateral arrangement (TTCA) would be used. This would effectively eliminate the need for the extension of bankruptcy safe harbors for such transactions. Second, overnight tri-party repos dominate the US repo markets, whereas tri-party repos only constitute a small fraction of the EU repo markets. Third, the average maturity of US repos is shorter than that of EU repos. Fourth, the EU repo markets are dominated by the government backed repos, namely, the collateral used to secure the repo is government securities. Fifth, although there is no considerable difference in the regulation governing rehypothecation of collateral across the Atlantic, in Europe there is no harmonized limit on rehypothecation. In contrast, in the US, such rehypothecation is capped at $140 \%$ of the liabilities of the client to the broker-dealer. The rest of the regulatory treatment of rehypothecation across the Atlantic remains virtually uniform. Finally, regarding bankruptcy safe harbors, by revising the FCD, the BRRD allows for a stay on close-out netting and enforcement provision for up to 48 hours, ${ }^{192}$ which is intended to afford resolution authorities with adequate time for an orderly resolution. As of this writing, despite heated discussions and new proposals in the US, ${ }^{193}$ there has been no equivalent change in the bankruptcy framework of repos in the US.

With respect to the MMFs, first, the EU has a very small MMF sector. Second, within this small MMF sector, the VNAV structure is prevalent. Third, the investor base of MMFs in the EU is predominantly

\footnotetext{
192 See BBRD, arts. 70-71 and 118 that revises the FCD by inserting a new article 1(6) to that directive.

${ }^{193}$ For an overview of these proposals, see Kirshner, "The Bankruptcy Safe Harbor in Light of Government Bailouts: Reifying the Significance of Bankruptcy as a Backstop to Financial Risk."
} 
composed of institutional investors. Fourth, there is a geographic disparity in the distribution of the MMFs in the EU, and it is likely that in certain jurisdictions the MMFs are more systemic than others. Fifth, a significant difference in the structure of the MMF industry in the EU and the US relates to the distinction between the government MMFs and Prime MMFs in the US. Such a distinctive category does not exist in the EU and hence the regulations do not treat them differently. Given the small size of government CNAV funds in the EU, there has been no need for introducing a similar legislative categorization to that of the US for such funds in the EU. However, the EU regulation introduces such categorization with distinctive rules for funds falling under those newly created categories, perhaps in anticipation of the proliferation of such funds in the future.

Based on our findings, we conclude that distinctive features of the EU shadow banking require a differentiated and tailor-made approach to regulating shadow banking. We specifically analyzed financial instruments, such as repos, which are predominantly associated with the shadow banking, and entities typically considered to be at the heart of the shadow banking system such as MMFs, and underlined their distinctive features. We conclude that given the substantial differences in all these elements of the shadow banking system, regulators, and particularly international standard setters, should be attentive of these differences and avoid a one-size-fits-all regulatory approach toward shadow banking. In particular, the international initiatives put forward by the FSB and the IOSCO should particularly take note of such subtleties in the structure of the shadow banking sector in different jurisdictions before attempting to shape global regulatory initiatives. 


\section{Bibliography}

Acharya, Viral V., Hemal Khandwala, and T. Sabri Öncü. "The Growth of a Shadow Banking System in Emerging Markets: Evidence from India." Journal of International Money and Finance 39 (12// 2013): 207-30.

Acharya, Viral V., and T. Sabri Öncü. "A Proposal for the Resolution of Systemically Important Assets and Liabilities: The Case Ofthe Repo Market." International Journal of Central Banking 9, no. S1 (January 2013 2013): 291-349.

Acharya, Viral V., Philipp Schnabl, and Gustavo Suarez. "Securitization without Risk Transfer." Journal of Financial Economics 107, no. 3 (3// 2013): 515-36.

Adrian, Tobias, and Adam B. Ashcraft. "Shadow Banking Regulation." Federal Reserve Bank of New York Staff Report, no. 559 (2012).

Aitken, James, and Manmohan Singh. Deleveraging after Lehman--Evidence from Reduced Rehypothecation (Epub). Vol. 9: International Monetary Fund, 2009.

Allahrakha, Meraj, Jill Cetina, and Benjamin Munyan. "Do Higher Capital Standards Always Reduce Bank Risk? The Impact of the Basel Leverage Ratio on the U.S. Triparty Repo Market." Office of Financial Research Working Paper (November 10, 2016 2016).

Antinolfi, G., F. Carapella, C. Kahn, A. Martin, D. C. Mills, and E. Nosal. "Repos, Fire Sales, and Bankruptcy Policy." Review of Economic Dynamics 18, no. 1 (2015/01/01/ 2015): 21-31.

Autorité des Marchés Financiers (AMF). "The Reuse of Assets: Regulatory and Economic Issues." (November 9, 2016).

Avraham, Dafna, Patricia Selvaggi, and James Vickery. "A Structural View of Us Bank Holding Companies." FRBNY Economic Policy Review 18, no. 2 (July 2012 2012): 65-81.

Bakk-Simon, Klára, Stefano Borgioli, Celestino Girón, Hannah Sabine Hempell, Angela Maddaloni, Fabio Recine, and Simonetta Rosati. "Shadow Banking in the Euro Area: An Overview." ECB Occasional Paper Series No 133 (2012).

Baklanova, Viktoria, Adam Copeland, and Rebecca McCaughrin. "Reference Guide to Us Repo and Securities Lending Markets." In Federal Reserve Bank of New York Staff Reports. New York: Federal Reserve Bank of New York, 2015.

Bank of England. "Financial Stability Report." London, 2011.

Bengt Holmström, and Jean Tirole. "Private and Public Supply of Liquidity." Journal of Political Economy 106, no. 1 (1998): 1-40.

Bengtsson, Elias. "Shadow Banking and Financial Stability: European Money Market Funds in the Global Financial Crisis." Journal of International Money and Finance 32 (2// 2013): 579-94.

Benjamin, Joanna, Guy Morton, and Michael Raffan. "The Future of Securities Financing." Law and Financial Markets Review 7, no. 1 (2013/01/28 2013): 4-8.

Blair, William. "Reconceptualizing the Role of Standards in Supporting Financial Regulation." Chap. 21 In Reconceptualising Global Finance and Its Regulation, edited by Ross P. Buckley, Emilios Avgouleas and Douglas W. Arner, 442-54. New York: Cambridge University Press, 2016.

Bliss, Robert R., and George G. Kaufman. "Derivatives and Systemic Risk: Netting, Collateral, and Closeout." Journal of Financial Stability 2, no. 1 (4// 2006): 55-70.

Borio, Claudio. "The Financial Cycle and Macroeconomics: What Have We Learnt?". Journal of Banking \& Finance 45 (2014/08/01/ 2014): 182-98.

Borio, Claudio, and Piti Disyatat. "Global Imbalances and the Financial Crisis: Link or No Link?". BiS Working Papers No 346 (2011).

Brady, Steffanie A, Ken E Anadu, and Nathaniel R Cooper. "The Stability of Prime Money Market Mutual Funds: Sponsor Support from 2007 to 2011." Federal Reserve Bank of Boston Risk and Policy Analysis Unit Working Paper RPA 12-3 (2012). 
Copeland, Adam, Darrell Duffie, Antoine Martin, and Susan McLaughlin. "Key Mechanics of the Us TriParty Repo Market." Federal Reserve Bank of New York Economic Policy Review 18, no. 3 (2012): 17-28.

Doyle, Nicola, Lieven Hermans, Philippe AM Molitor, and Christian Weistroffer. "Shadow Banking in the Euro Area: Risks and Vulnerabilities in the Investment Fund Sector." ECB Occasional Paper Series, no. 174 (June 2016 June 2016).

Duclos, Christophe, and Romuald Morhs. "Analysis on the Shadow Banking Content of Captive Financial Companies in Luxembourg." Luxembourg: Banque Centrale du Luxembourg, Comité du Risque Systémique, 2017.

Duffie, Darrell. "The Failure Mechanics of Dealer Banks."

Duffie, Darrell, and David A Skeel. "A Dialogue on the Costs and Benefits of Automatic Stays for Derivatives and Repurchase Agreements." (2012).

Edwards, Franklin R, and Edward R Morrison. "Derivatives and the Bankruptcy Code: Why the Special Treatment." Yale Journal on Regulation 22 (2005): 91.

European Banking Authority. "Report to the European Commission on the Perimeter of Credit Institutions Established in the Member States." London, 27 November 2014.

European Central Bank. Financial Stability Review. May 2016.

. "Report on Financial Structures." Frankfurt am Main, 2017.

. "Report on Financial Structures." Frankfurt am Main, 2016.

"Report on Financial Structures." (October 2015).

European Commission. "Consultation Document; Undertakings for Collective Investment in Transferable Securities (Ucits): Product Rules, Liquidity Management, Depositary, Money Market Funds, Long-Term Investments." Brussels, 2012.

. "Economic Analysis Accompanying the Document Communication from the Commission to the European Parliament, the Council, the European Economic and Social Committee and the Committee of the Regions Action Plan on Building a Capital Markets Union." Brussels: European Commission, 2015.

. "New Rules for Money Market Funds Proposed - Frequently Asked Questions." Brussles, 4 September 2013.

. "Regulation on Transparency of Securities Financing Transactions and of Reuse: Frequently Asked Questions." Brussels, 29 October 2015.

European Systemic Risk Board. "ESRB Opinion to Esma on Securities Financing Transactions and Leverage under Article 29 of the Sftr." 2016.

. "Recommendation of the ESRB of 22 December 2011 on Us Dollar Denominated Funding of Credit Institutions (Esrb/2011/2)." 2011.

Faubus, Bryan G. "Narrowing the Bankruptcy Safe Harbor for Derivatives to Combat Systemic Risk." Duke Law Journal 59, no. 4 (2010): 801-42.

Fawley, Brett W, and Christopher J Neely. "Four Stories of Quantitative Easing." Federal Reserve Bank of St. Louis Review 95, no. 1 (2013): 51-88.

Financial Stability Board. "Global Shadow Banking Monitoring Report 2015." Basel, 2015. . "Global Shadow Banking Monitoring Report 2016." 2017.

. "Global Shadow Banking Monitoring Report 2017." Basel, Switzerland: Financial Stability Board, 5 March 2018.

. "Progress in the Implementation of the G20 Recommendations for Strengthening Financial Stability: Report of the Financial Stability Board to G20 Finance Ministers and Central Bank Governors." 2011.

. "Securities Lending and Repos: Market Overview and Financial Stability Issues- Interim Report of the Fsb Workstream on Securities Lending and Repos." Basel, Switzerland, 2012.

"Shadow Banking: Scoping the Issues, a Background Note of the Financial Stability Board." 2011. 
. "Shadow Banking: Strengthening Oversight and Regulation-- Recommedations of the Financial Stability Board." 2011.

. "Shadow Banking: Strengthening Oversight and Regulation: Recommedations of the Financial Stability Board." 2011.

. "Strengthening Oversight and Regulation of Shadow Banking: An Integrated Overview of Policy Recommendations." Basel: Financial Stability Board, 18 November 2012.

. "Strengthening Oversight and Regulation of Shadow Banking: Policy Framework for

Strengthening Oversight and Regulation of Shadow Banking Entities." Financial Stability Board, 2013.

. "Transforming Shadow Banking into Resilient Market-Based Finance: Regulatory Framework for Haircuts on Non-Centrally Cleared Securities Financing Transactions." Basel, Switzerland, 2015.

Financial Stability Oversight Council. "Financial Stability Oversight Council (Fsoc) 2016 Annual Report." Washington, D.C.: Financial Stability Oversight Council, 2016.

Fisch, Jill E. "The Broken Buck Stops Here: Embracing Sponsor Support in Money Market Fund Reform." North Carolina Law Review 93 (2014): 935-93.

Gelpern, Anna, and Erik F. Gerding. "Rethinking the Law in "Safe Assets"." Chap. 9 In Reconceptualising Global Finance and Its Regulation, edited by Ross P. Buckley, Emilios Avgouleas and Douglas W. Arner, 159- 89. New York: Cambridge University Press, 2016.

Ghosh, Swati, Ines Gonzalez del Mazo, and İnci Ötker-Robe. "Chasing the Shadows: How Significant Is Shadow Banking in Emerging Markets?". The World Bank- Economic Premise, no. 88 (2012): 17.

Goralnik, Nathan. "Bankruptcy-Proof Finance and the Supply of Liquidity." Yale Law Journal 122 (2012): 460-506.

Gorton, Gary B. Slapped by the Invisible Hand: The Panic of 2007. New York: Oxford University Press, 2010.

Gorton, Gary B., and Andrew Metrick. "Regulating the Shadow Banking System." Brookings Papers on Economic Activity (2010): 261-312.

—. "Securitized Banking and the Run on Repo." Journal of Financial Economics 104, no. 3 (2012): 425-51.

Gorton, Gary, Stefan Lewellen, and Andrew Metrick. "The Safe-Asset Share." The American Economic Review 102, no. 3 (2012): 101-06.

Grillet-Aubert, Laurent, Jean-Baptiste Haquin, Clive Jackson, Neill Killeen, and Christian Weistroffer. "Assessing Shadow Banking- Non-Bank Financial Intermediation in Europe." Frankfurt am Main: European Systemic Risk Board, 2016.

Harris, Daniel. "Use of Customer Securities by Uk Prime Brokers: The Road Ahead." Law and Financial Markets Review 7, no. 2 (2013/03/28 2013): 107-11.

Holmstrom, Bengt. "Understanding the Role of Debt in the Financial System." BIS Working Paper No 479 (2015).

Huang, Robin Hui. "Shadow Banking and Its Regulation: The Case of China." Chap. 17 In Reconceptualising Global Finance and Its Regulation, edited by Ross P. Buckley, Emilios Avgouleas and Douglas W. Arner, 340-54. New York: Cambridge University Press, 2016.

Johnson, Christian A. "Derivatives and Rehypothecation Failure: It's 3:00 Pm, Do You Know Where Your Collateral Is?". Arizona Law Review 30 (1997): 949-1001.

International Capital Market Association. "Frequently Asked Questions on Repo." edited by International Capital Market Association (ICMA), 2015.

International Capital Markets Association. "Perspectives from the Eye of the Storm: The Current State and Future Evolution of the European Repo Market." ICMA, 2015.

International Capital Market Association (ICMA). "European Repo Market Survey." (March 2018).

__. "European Repo Market Survey: Number 33 - Conducted June 2017." (October 2017). 
International Monetary Fund. "Global Financial Stability Report: Risk Taking, Liquidity, and Shadow Banking: Curbing Excess While Promoting Growth." Washington, DC: International Monetary Fund, October 2014.

_ . "Global Financial Stability Report: The Quest for Lasting Stability." Washington, DC: International Monetary Fund, April 2012.

International Organization of Securities Commission (IOSCO). "Policy Recommendations for Money Market Funds." October 2012.

Kacperczyk, Marcin, and Philipp Schnabl. "How Safe Are Money Market Funds?*." The Quarterly Journal of Economics 128, no. 3 (2013): 1073-122.

Kirshner, Jodie A. "The Bankruptcy Safe Harbor in Light of Government Bailouts: Reifying the Significance of Bankruptcy as a Backstop to Financial Risk." NYUJ Legislation and Public Policy 18 (2015): 795-836.

Krishnamurthy, Arvind, Stefan Nagel, and Dmitry Orlov. "Sizing up Repo." The Journal of Finance 69, no. 6 (2014): 2381-417.

Levine, Ross. "Bank-Based or Market-Based Financial Systems: Which Is Better?". Journal of Financial Intermediation 11, no. 4 (2002/10/01 2002): 398-428.

Lubben, Stephen J. "The Bankruptcy Code without Safe Harbors." American Bankruptcy Law Journal 84 (2010): 123-44.

. "Derivatives and Bankruptcy: The Flawed Case for Special Treatment." University of Pennsylvania Journal of Business Law 12, no. 1 (2009): 61-78.

. "Repeal the Safe Harbors." American Bankruptcy Institute Law Review 18 (2010): 319-35.

Michel, Norbert J. "Fixing the Regulatory Framework for Derivatives." Washington, D.C., 2016.

Mooney, Charles W. "The Bankruptcy Code's Safe Harbors for Settlement Payments and Securities Contracts: When Is Safe Too Safe?". Texas International Law Journal 49 (2014): 245-69.

Nabilou, Hossein. "Can the Plight of the European Banking Structural Reforms Be a Blessing in Disguise?". SSRN Working Paper Series (2019).

. "The Eu Framework for Bank Capital Regulation and Repo Collateral." SSRN Working Paper Series (2017).

Nabilou, Hossein, and Alessio Pacces. "The Law and Economics of Shadow Banking." In Research Handbook in Shadow Banking, edited by Iris H. Chiu, forthcoming 2017.

. "The Law and Economics of Shadow Banking." Chap. 1 In Research Handbook on Shadow Banking: Legal and Regulatory Aspects, edited by Iris H. Chiu and Iain G. MacNeil, 7-46. Cheltenham, UK: Edward Elgar Publishing Inc., 2018.

Paech, Philipp. "Shadow Banking: Legal Issues of Collateral Assets and Insolvency Law." Brussels: European Parliament; Directorate General for Internal Policies; Policy Department A: Economics and Scientific Policy, 2013.

. "The Value of Insolvency Safe Harbours." LSE Legal Studies Working Paper No. 9/2015 (2015).

Parlatore, Cecilia. "Fragility in Money Market Funds: Sponsor Support and Regulation." Journal of Financial Economics 121, no. 3 (2016/09/01/ 2016): 595-623.

Perotti, Enrico. "Systemic Liquidity Risk and Bankruptcy Exceptions." CEPR Policy Insight, no. 52 (2010).

Pozsar, Zoltan. "Shadow Banking: The Money View." Office of Financial Research Working Paper (July 02, 2014 2014).

Prüm, André. In the Shadow of the Banks. Cowansville (Québec): Thomson Reuters, 2014.

Ricks, Morgan. The Money Problem: Rethinking Financial Regulation. Chicago: University of Chicago Press, 2016.

Saunders, Anthony, and Ingo Walter. Universal Banking in the United States: What Could We Gain? What Could We Lose? New York: Oxford University Press, 1994.

Schwarcz, Steven L. "Derivatives and Collateral: Balancing Remedies and Systemic Risk." University of Illinois Law Review 2015, no. 2 (2015): 699-720. 
"Distorting Legal Principles." Journal of Corporation Law 35, no. 4 (2010): 697-727.

Scott, Hal. "Interconnectedness and Contagion." Available at SSRN (2012).

Shleifer, Andrei. "Comments and Discussions (Regulating the Shadow Banking System by Gary Gorton \& Andrew Metrick)." Brookings Papers on Economic Activity (2010): 298-303.

Singh, Manmohan. "Velocity of Pledged Collateral: Analysis and Implications." IMF Working Paper WP/11/256 (2011).

Singh, Manmohan, and James Aitken. "The (Sizable) Role of Rehypothecation in the Shadow Banking System." IMF Working Paper 10/172 (2010).

Sissoko, Carolyn. "The Legal Foundations of Financial Collapse." Journal of Financial Economic Policy 2, no. 1 (2010): 5-34.

Skeel, David A., and Thomas H. Jackson. "Transaction Consistency and the New Finance in Bankruptcy." Columbia Law Review 112, no. 1 (2012): 152-202.

Stulz, René M. "Should We Fear Derivatives?". The Journal of Economic Perspectives 18, no. 3 (2004): 173-92.

Supervision, Basel Committee on Banking. "Identification and Management of Step-in Risk - Second Consultative Document." 2017.

Tang, Yingmao. "Shadow Banking or "Bank's Shadow": Reconceptualising Global Shadow Banking Regulation." Chap. 16 In Reconceptualising Global Finance and Its Regulation, edited by Ross P. Buckley, Emilios Avgouleas and Douglas W. Arner, 326-39. New York: Cambridge University Press, 2016.

The Financial Crisis Inquiry Commission. "The Financial Crisis Inquiry Report: Final Report of the National Commission on the Causes of the Financial and Economic Crisis in the United States." Washington, D.C., 2011.

Willen, Paul. "Mandated Risk Retention in Mortgage Securitization: An Economist's View." American Economic Review 104, no. 5 (2014): 82-87.

Wymeersch, Eddy. "Shadow Banking and Systemic Risk." European Banking Institute Working Paper Series No. 1 (2017). 